\title{
On the Structure of the Regional-Scale Circulation over Central Africa: Seasonal Evolution, Variability, and Mechanisms ${ }^{\circ}$
}

\author{
GEORGES-NOEL T. LONGANDJO \\ Department of Oceanography, and Nansen-Tutu Centre for Environmental Marine Research, University of Cape Town, \\ Cape Town, South Africa, and Faculty of Environmental Science and Engineering, Université Nouveaux Horizons, \\ Lubumbashi, Democratic Republic of the Congo \\ MATHiEu Rouault \\ Department of Oceanography, and Nansen-Tutu Centre for Environmental Marine Research, University of Cape Town, \\ Cape Town, South Africa
}

(Manuscript received 4 March 2019, in final form 17 September 2019)

\begin{abstract}
Atmospheric circulation over central Africa is dominated by the tropical easterly jet, the African easterly jet, and the low-level westerly jet. In the lower troposphere, a zonal overturning cell occurs over central Africa, but the mechanisms driving its formation, seasonal evolution, and variability are still unclear. Here, using reanalyses (ERA-Interim, NCEP-2, and JRA-55) and the ECHAM5.3 atmospheric model forced by observed sea surface temperature, we highlight the existence, in the lower troposphere, of a separated single, closed, counterclockwise, and shallow zonal overturning cell, namely, the Congo basin cell. This Congo basin cell persists year round, with maximum intensity and width in August/September and minimum intensity and width in May. This shallow cell extracts heat from the warm central Africa landmass through latent and internal energies and transports it to the cold eastern equatorial Atlantic Ocean, reminiscent of the mixed Carnot-steam cycle. Indeed, the monsoon-like circulation triggered by the zonal surface pressure gradient between the warm central Africa landmass and surrounding cold oceans produces mass convergence at the Congo Air Boundary, providing necessary upward motion to air parcels to destabilize the atmosphere over central Africa. As result, convective updrafts depend on underlying moist static energy and the induced lowlevel westerly jet, controlled by the near-surface land-ocean thermal contrast through the zonal surface pressure gradient between the warm central African landmass and cold eastern equatorial Atlantic Ocean, rather than the midlevel easterly jet. This midlevel easterly jet is formed by the mechanical work that balances the convection associated with the saturation and rainfall. Furthermore, the efficiency of the Congo basin cell determines seasonality over central Africa.
\end{abstract}

\section{Introduction}

Wind plays a crucial role in redistributing energy and moisture, which in turn are likely to influence temperature and precipitation patterns. Over central Africa, the annual cycle of rainfall is primarily dominated by the change of atmospheric pressure system and its associated Hadley and Walker circulations rather than by local temperature

Supplemental information related to this paper is available at the Journals Online website: https://doi.org/10.1175/JCLI-D-190176.s1.

Corresponding author: Georges-Noel T. Longandjo, longandjo@ gmail.com and water vapor (G. Longandjo et al. 2018, unpublished manuscript). Little is known about the regional-scale circulation over central Africa. McCollum et al. (2000) reported that the low-level westerly jet over the Atlantic Ocean supplied moisture to central Africa inland, and Vigaud et al. (2009) outlined the important role played by this low-level westerly jet to deepen convection in summer. Nicholson and Grist (2003) found the existence of the African easterly jet (AEJ) and tropical easterly jet (TEJ) in the middle $(\sim 600 \mathrm{hPa})$ and upper $(200 \mathrm{hPa})$ troposphere over central Africa, respectively. They also added that the AEJ does influence the development of the rainy season. Pokam et al. (2012) argued that the recycling of precipitation over central Africa is regulated by both low-level moisture flux direction and strength at seasonal 
time scale, with the seasonal migration of the rainfallmaximum position (intertropical convergence zone) controlled by the vertical moist instability (Suzuki 2011).

Another viewpoint is to consider this low-level westerly jet as the lower branch of the Walker-like cell over central Africa. Indeed, some papers (Flohn 1971; Flohn and Fleer 1975; Webster 1983; Yu and Zwiers 2010; Yu et al. 2012; Bayr et al. 2014; Pokam et al. 2014; Thorsten and Richter 2014; Cook and Vizy 2016; Neupane 2016) suggested the existence of Walker-like cells over central Africa. Flohn (1971, see his Fig. 12) and Flohn and Fleer (1975) depicted a dominant asymmetric overturning circulation over central Africa, with low-level westerlies supplying water vapor from the eastern Atlantic as its lower branch. Over the Rift Valley highlands $\left(\sim 33^{\circ} \mathrm{E}\right)$ warm air uplifts (rising branch) while at upper levels the dominant TEJ forms the returning branch. Over the eastern Atlantic, the air subsides, constituting the closing branch. On the other hand, Webster (1983) and Thorsten and Richter (2014, see their Fig. 13) found symmetrical overturning cells, with convergent branches at low levels, with moist air flowing from surrounding oceans into the central African landmass. The ascending branch is located over the central African landmass. At upper levels, the upward motion diverges into what are considered as the two return branches, before sinking over the eastern Atlantic and western Indian Oceans respectively, closing the circulation. With respect to the seasons, the ascending branch is located either over eastern Africa or over the eastern Atlantic (Atlantic coastal region). This inconsistency indicates that the regional-scale atmospheric dynamics over central Africa has not yet been carefully studied and remains widely undocumented.

Furthermore, at low levels, Pokam et al. (2014) found that the Walker-like circulation is driven by divergent circulation over equatorial central Africa $\left(15^{\circ}-45^{\circ} \mathrm{E}, 0^{\circ}-\right.$ $10^{\circ} \mathrm{N}$ ), with the low-level branch (low-level westerlies between $10^{\circ}$ and $15^{\circ} \mathrm{E}$ ), controlled by the differential adiabatic heating between central Africa and the eastern Atlantic Ocean. Using European Centre Hamburg Model (ECHAM; AMIP-type) simulations, Hua et al. (2018) suggested that the better the equatorial Walker circulation is reproduced, then the better the drought over central Africa is captured. Cook and Vizy (2016) and Neupane (2016) also reported the existence of the zonal overturning circulation over the Congo basin $\left(15^{\circ}-\right.$ $\left.25^{\circ} \mathrm{E}, 3^{\circ} \mathrm{S}-3^{\circ} \mathrm{N}\right)$, which forms only from July to September (Neupane 2016) or from June to October (Cook and Vizy 2016). This zonal overturning circulation over central Africa occurs when the Atlantic cold-tongue sea surface temperature (SST) matures to set up favorable atmospheric conditions for its development (Cook and Vizy 2016), and Neupane (2016) suggested that the low- level westerly jet is controlled by the land-ocean thermal contrast between central Africa and the eastern Atlantic Ocean. However, Cook and Vizy (2016) suggest that equatorial Atlantic SST variation is not associated with the interannual variability in the strength of this shallow overturning circulation. It is not yet entirely clear what the physical mechanisms are that are responsible for the development and maintenance of this low-level zonal overturning circulation over central Africa. In addition, this zonal overturning circulation over central Africa is timed out of phase with central African rainfall, but it does play a crucial role in regulating precipitation over the Sahel and western Africa (Cook and Vizy 2016; Neupane 2016).

Nonetheless, when the zonal circulation is assumed to be thermally driven by the divergent component of the zonal wind, the climatological annual mean of the mass-weighted streamfunctions-computed as in $\mathrm{Yu}$ and Zwiers (2010) and Yu et al. (2012) - shows a zonal overturning circulation associated with a strong ascent motion over central Africa (see Fig. S1 in the online supplemental material). This Walker-like cell over central Africa is centered at low levels, around $\sim 800 \mathrm{hPa}$, and it is not separated from the circulation aloft, consistent with many papers (Yu and Zwiers 2010; Yu et al. 2012; Bayr et al. 2014; Pokam et al. 2014; Cook and Vizy 2016). Moreover, the seasonal cycle of this Walker-like circulation over central Africa shows that the center of this zonal overturning cell shifts from $\sim 800$ to $700 \mathrm{hPa}$ (see Fig. S2 in the online supplemental material). It may be this low-level position of the center of the Walker-like cell over central Africa that was mistaken as a low-level overturning cell in Pokam et al. (2014) and Cook and Vizy (2016). Therefore, this indicates that there is no existence of a separated zonal overturning at lower troposphere as previously reported.

In this paper, we aim to complement previous works (Pokam et al. 2014; Cook and Vizy 2016; Neupane 2016) and to unravel what the physical processes are that are responsible for the low-level zonal overturning circulation formation, seasonal evolution, and variability. Also, this study will try to provide comprehensive insight into the connection between this zonal overturning circulation and local rainfall. So, the scope of this paper is limited to answer the following questions:

1) What is the structure of the regional-scale zonal circulation over central Africa?

2) How does the central African zonal overturning cell form and what are its drivers?

3) What are the relations between the central African zonal overturning cell and the local rainfall? 


\section{Data and methods}

\section{a. Data}

To investigate the structure of the regional-scale circulation over central Africa, we choose to use the widespread global reanalyses not only because they are intensively used within the climate research communities, but mostly because the observational datasets are not reliable over central Africa (see Text S1 and Fig. S3 in the online supplemental material)—no radiosondes are performed and collected climate data are sporadic. For instance, only three stations in the Democratic Republic of the Congo reported to the Global Telecommunications System (GTS) in 2013 (Washington et al. 2013). The atmospheric variables employed in this study have been taken from the European Centre for Medium-Range Weather Forecasts (ECMWF) interim reanalysis (ERA-Interim; Dee et al. 2011) because this dataset better represents the hydrological cycle over central Africa than do other datasets (Siam et al. 2013) and from the National Centers for Environmental Prediction (NCEP)-Department of Energy (DOE) Atmospheric Model Intercomparison Project (AMIP)-II Reanalysis (NCEP-2) data (Kanamitsu et al. 2002) because they better capture wind and geopotential height fields over central Africa than do other reanalyses (Hua et al. 2019). The Japanese reanalysis (JRA-55) dataset produced by the Japan Meteorological Agency (JMA) numerical assimilation and forecast system (Kobayashi et al. 2015) is also used to evaluate its ability to capture the regional-scale zonal circulation over central Africa. ERA-Interim has 37 vertical levels, and NCEP2 and JRA-55 have 17 vertical levels. Here, only the pressure levels that are common to all three reanalyses are considered $(1000,925,850,700,600,500,400,300,250,200$, 150 , and $100 \mathrm{hPa}$ ) at monthly time steps. The mean sea level pressure at monthly time steps is also used. ERAInterim has a $0.75^{\circ}$ horizontal resolution, and NCEP-2 and JRA-55 have $2.5^{\circ} \times 2.5^{\circ}$ horizontal resolutions. ERA-Interim and NCEP-2 cover the period from 1979 to 2017, and JRA-55 covers the period from 1958 to 2012. For rainfall, we used the mean of the Climate Prediction Center Merged Analysis of Precipitation (CMAP) dataset (Xie and Arkin 1997) and the Global Precipitation Climatology Project (GPCP) monthly precipitation dataset (Huffman et al. 2009), as suggested by Asadullah et al. (2008). The CMAP and GPCP datasets are compiled from merged satellite precipitation data and are bias corrected over land through continental rain gauge observations (Bolvin et al. 2009); they are available at monthly temporal resolution (from 1979 to the present) at $2.5^{\circ} \times 2.5^{\circ}$. To further understand the role of SST on central African regional-scale dynamics, we used ECHAM, version 5.3 (ECHAM5.3), from the Max Planck Institute for Meteorology, which is an atmospheric-only general circulation model forced by observed SST. Hua et al. (2018) assessed how well ECHAM simulates precipitation and atmospheric circulations over central Africa, but many studies (Gleixner et al. 2017; Mohino et al. 2011; Sperber et al. 2013) pointed out the good performance of ECHAM, version 5 , to document the tropical climate variability and predictability. A more detailed description of ECHAM5.3 is given in Roeckner et al. (2003). The ECHAM5.3 simulations consist of a five-member ensemble of historical simulations forced with the ERSST monthly SSTs (Gleixner et al. 2017). Total precipitation is obtained from convective and large-scale precipitation, respectively. We also used mean sea level pressure, air temperature, geopotential, specific humidity, and zonal and meridional wind components at the same pressure levels as in the reanalyses; the spatial resolution is gridded at $1.125^{\circ} \times 1.125$. The ECHAM5.3 model spans from 1979 to 2009 .

\section{b. Method}

To better understand the regional-scale zonal circulation over central Africa, we used the mass-weighted streamfunction because it is commonly used for its counterpart Hadley circulation (Oort and Yienger 1996; Stachnik and Schumacher 2011; Donohoe et al. 2013; etc.) instead of using the vertical velocity at specific pressure level (Hua et al. 2016; Dezfuli et al. 2015) or the divergent component of the zonal wind (Pokam et al. 2014; Yu and Zwiers 2010; Yu et al. 2012; Bayr et al. 2014; Cook and Vizy 2016). The primary reason is that the mass-weighted streamfunction will help us to objectively define indices that describe the regional-scale circulation over central Africa in terms of intensity and width on various time scales.

Following Cook (2003), the conservation of mass, in vertical coordinates, must satisfy the equation

$$
\frac{1}{R \cos \theta} \frac{\partial u}{\partial \phi}+\frac{1}{R \cos \theta} \frac{\partial(v \cos \theta)}{\partial \theta}+\frac{\partial \omega}{\partial p}=0,
$$

where $u$ and $v$ are the zonal and meridional wind components, $\omega$ is the vertical velocity, $R$ is Earth's radius, $\phi$ is the longitude, $\theta$ is the latitude, and $p$ is the pressure level. When Eq. (1) is averaged over latitude, the second term on the left-hand side of the equation is zero. Therefore, Eq. (1) can be written, with square brackets denoting the meridional average, as

$$
\frac{1}{R \cos \theta} \frac{\partial[u]}{\partial \phi}+\frac{\partial[\omega]}{\partial p}=0 .
$$


From Eq. (2), one could state that if one component $([u]$ or $[\omega])$ is known, the other can be identified. This means that one variable can be used to fully determine the two-dimensional flow. The continuity and hydrostatic equations allow us to express the combined circulation $[u]$ and $[\omega]$ in terms of mass-weighted (or Stokes) streamfunctions $\psi$, which define the total eastward mass flux above a given pressure level and longitude:

$$
\begin{aligned}
& {[u]=\frac{g}{2 \pi R} \frac{\partial \psi}{\partial p} \text { and }} \\
& {[\omega]=-\frac{g}{2 \pi R^{2}} \frac{\partial \psi}{\partial p},}
\end{aligned}
$$

with $g=9.8 \mathrm{~m} \mathrm{~s}^{-1}$ being the gravitational constant.

By solving for $\psi$, we found the following solution:

$$
\psi(p, \phi)=2 \pi R\langle[u]\rangle,
$$

with the angle brackets denoting the mass-weighted vertical integration from the surface to $100 \mathrm{hPa}$ :

$$
\langle A\rangle=\frac{1}{g} \int_{100-\mathrm{hPa}}^{\text {surface }} A d p .
$$

The zonal mass-weighted streamfunction will be applied to characterize the Walker-like circulation over central Africa. We use following convention: when the mass-weighted streamfunction is positive, it corresponds to clockwise circulation, whereas counterclockwise circulation corresponds to the negative mass-weighted streamfunction. The unit of the mass-weighted streamfunction is Sverdrups $\left(1 \mathrm{~Sv}=10^{9} \mathrm{~kg} \mathrm{~s}^{-1}\right)$. This definition is also equivalent to $10^{6} \mathrm{~m}^{3} \mathrm{~s}^{-1}$, corresponding to the mass flux produced by a 1-Sv flow of water of $10^{3} \mathrm{~kg} \mathrm{~m}^{-3}$ of density. To provide an overview of the evolution of the central African zonal circulation structure, all metrics defined in our analyses emphasize the annual cycle of the meridional-mean circulation, particularly at low levels. The zonal wind is averaged meridionally between $5^{\circ} \mathrm{N}$ and $5^{\circ} \mathrm{S}$, before computing the mass-weighted streamfunctions. However, when averaged over central African latitudes (i.e., between $10^{\circ} \mathrm{N}$ and $15^{\circ} \mathrm{S}$ ), the low-level zonal circulation is still visible, but with smaller extension, while its strength remains somewhat of the same range. It is important to note that over East Africa the interpretation of the regional circulation at low levels, particularly between 1000 and $925 \mathrm{hPa}$, should be cautious as it could be either artifacts of the zonal circulation in the used reanalysis datasets or below the surface.

\section{Results}

a. Walker-like circulation over central Africa: Climatology, annual cycle, and variability

\section{1) Mean-state structure of the REGIONAL-SCALE ZONAL CIRCULATION OVER CENTRAL AFRICA AND ITS SEASONALITY}

Figure 1 represents the climatological annual (all months) mean of the mass-weighted streamfunctions (contours) and its associated vertical motion (shaded) over central Africa in ERA-Interim, NCEP2, and JRA-55. The regional-scale zonal circulation over central Africa consists mostly of a predominant clockwise circulation associated with a strong rising motion $(\partial \psi / \partial p<0)$, indicative of deep convection (Fig. 1). This dominant easterly circulation has an ascending branch over the Rift valley highlands $\left(33^{\circ} \mathrm{E}\right)$, suggesting a surface forcing (Fig. S4 in the online supplemental material) and a subsiding branch over the equatorial Atlantic (west of $\sim 1^{\circ} \mathrm{W}$ ) (Figs. 1a-c). The induced strong convection associated with the resulted vertical motion $(\partial \psi / \partial p<0)$ occurs mainly over the central Africa landmass rather than over the surrounding oceans (Figs. 1a-c), as indicated by negative value of vertical velocity. The convection over the central African landmass is stronger in ERA-Interim (Fig. 1a) than in JRA-55 and NCEP-2, however (Figs. 1b,c). At upper levels ( $200 \mathrm{hPa})$, strong TEJs (Nicholson and Grist 2003) constitute the return branch, before gradually subsiding over the equatorial Atlantic (descending branch; Figs. 1a-c). Associated with the subsidence over the equatorial Atlantic, the low-level circulation remains easterly (west of $\sim 1^{\circ} \mathrm{W}$ ) so that there is no closing branch to complete this regional-scale zonal circulation (Figs. 1a-c). Neupane (2016) also reported the lack of the closing branch for the zonal circulation at low levels over West Africa. These low-level easterlies over the equatorial Atlantic (at west of $\sim 1^{\circ} \mathrm{W}$ ) are driven by the South Atlantic anticyclone through ocean-atmosphere processes (Cabos et al. 2017). This regional-scale zonal circulation is somewhat identical to the Walker-like circulation (Fig. S1), with strong ascent motion over central Africa, except at low levels, where there is a closing branch. This central African Walker-like cell is centered at low levels ( $~ 800 \mathrm{hPa})$, consistent with Pokam et al. (2014), with an ascending branch situated at $40^{\circ} \mathrm{E}$ (over East Africa), a subsiding branch at $\sim 15^{\circ} \mathrm{W}$ (over western equatorial Atlantic Ocean), and a return branch at upper levels $(\sim 200 \mathrm{hPa}$; Fig. S1). Here, the mass-weighted streamfunctions are computed as defined by $\mathrm{Yu}$ and Zwiers (2010) and Yu et al. (2012). The former regional-scale zonal circulation over equatorial central Africa with no closing branch at low levels (Figs. 1a-c) will be referred as the 
ERA-Interim

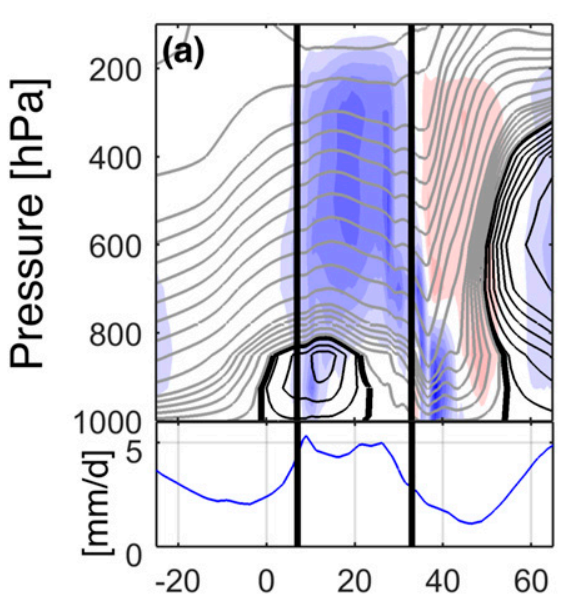

NCEP-2

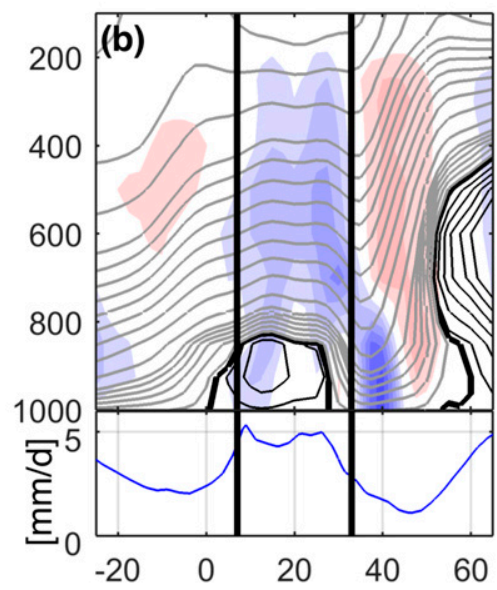

JRA55

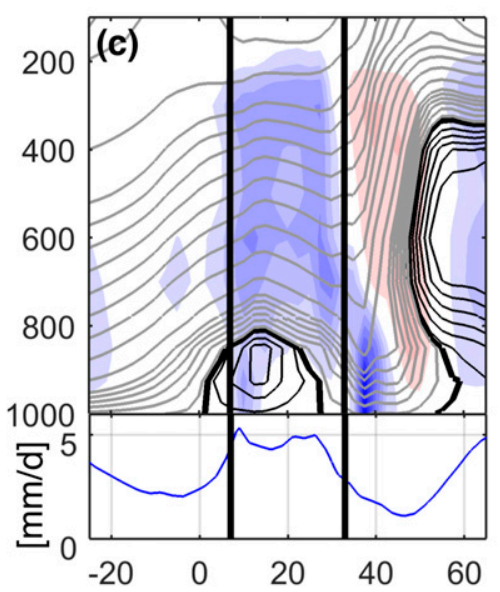

\section{Longitude [deg. east]}

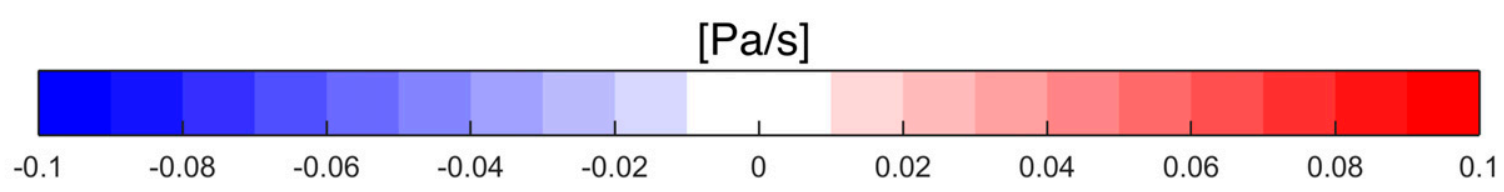

FIG. 1. Climatological annual (all months) mean of the zonal mass-weighted streamfunction (contours; Sv) and vertical velocity (shaded; $\mathrm{Pa} \mathrm{s}^{-1}$ ) and rainfall (bottom part of the panels; mm day ${ }^{-1}$ ) over central Africa for (a) ERA-Interim from 1979 to 2017, (b) NCEP2 from 1979 to December 2017, and (c) JRA-55 from 1958 to 2012. Gray and black contours represent positive and negative values of massweighted streamfunctions. Contour intervals are $20 \mathrm{~Sv}$ between 5 and $100 \mathrm{~Sv}, 75 \mathrm{~Sv}$ between 150 and $600 \mathrm{~Sv}$, and $150 \mathrm{~Sv}$ up to $700 \mathrm{~Sv}$. Vertical black bars represent the zonal limit of the central African region.

central African "pseudo" overturning cell in comparison with this latter, complete zonal overturning circulation (Fig. S1).

At low levels (between the surface and $800 \mathrm{hPa}$ ), a separated single, closed, counterclockwise, and shallow asymmetric zonal overturning cell is located between the climatological annual mean position of the ascending branch at $\sim 20.25^{\circ} \pm 5.68^{\circ} \mathrm{E}$ over the central African landmass and the climatological annual mean position of the sinking branch at $\sim 1.11^{\circ} \pm 4.25^{\circ} \mathrm{W}$ over the equatorial Atlantic in ERA-Interim (Fig. 1a), consistent with Neupane (2016). The ascending branch of this shallow zonal overturning cell is a convergence zone of monsoon-like circulations from the equatorial Atlantic and Indian Oceans toward the central African interior at low levels (Fig. 1a). For NCEP2 and JRA-55, the climatological annual mean position of the rising branch occurs at $26.05^{\circ} \pm 5.23^{\circ} \mathrm{E}$ and $24.23^{\circ} \pm 5.64^{\circ} \mathrm{E}$, while the climatological annual mean position of the subsiding branch occurs at $0.2^{\circ} \pm 4.57^{\circ} \mathrm{W}$ and $1.06^{\circ} \pm$ $4.18^{\circ} \mathrm{E}$, respectively (Figs. $1 \mathrm{~b}, \mathrm{c}$ ). At $\sim 800 \mathrm{hPa}$, the circulation starts to become westward $(\psi>0)$ over central Africa, indicative of a midlevel easterly jet (return branch). Over the equatorial Atlantic, the air parcels subside, and it is considered as a descending branch (Figs. 1a-c). The lower branch (east of $\sim 1^{\circ} \mathrm{W}$ ) consists of the low-level westerly jet (between near-surface and $850 \mathrm{hPa}$ ) flowing from equatorial Atlantic to central Africa inland, and so closing the circulation by forming a zonal shallow overturning cell (Figs. 1a-c). Hereinafter, this separated, closed, zonal, shallow overturning cell confined in the lower troposphere will be referred to as the Congo basin cell. Over East Africa and the equatorial Indian Ocean, the downward branch of the Walker cell is associated with subsidence (Figs. 1a-c and Fig. S3), as indicated by the positive value of the vertical velocity $(\partial \psi / \partial p>0)$. In East Africa, the low-level upward motion over the warm landmass associated with less moisture (Fig. S5d in the online supplemental material) is capped by a midlevel subsidence (Figs. 1a-c and Fig. S1), indicative of a thermal low (Johnson 2003).

The Congo basin cell is a thermally direct circulation, with warm air over the upward branch and relative cold air associated with subsidence over the descending branch (Figs. 1a-c and 2a; see also Figs. S5a,d), consistent with the climatological annual mean near-surface land-ocean thermal contrast $\left(\Delta T_{\mathrm{ATL}}\right)$, defined as the near-surface temperature 


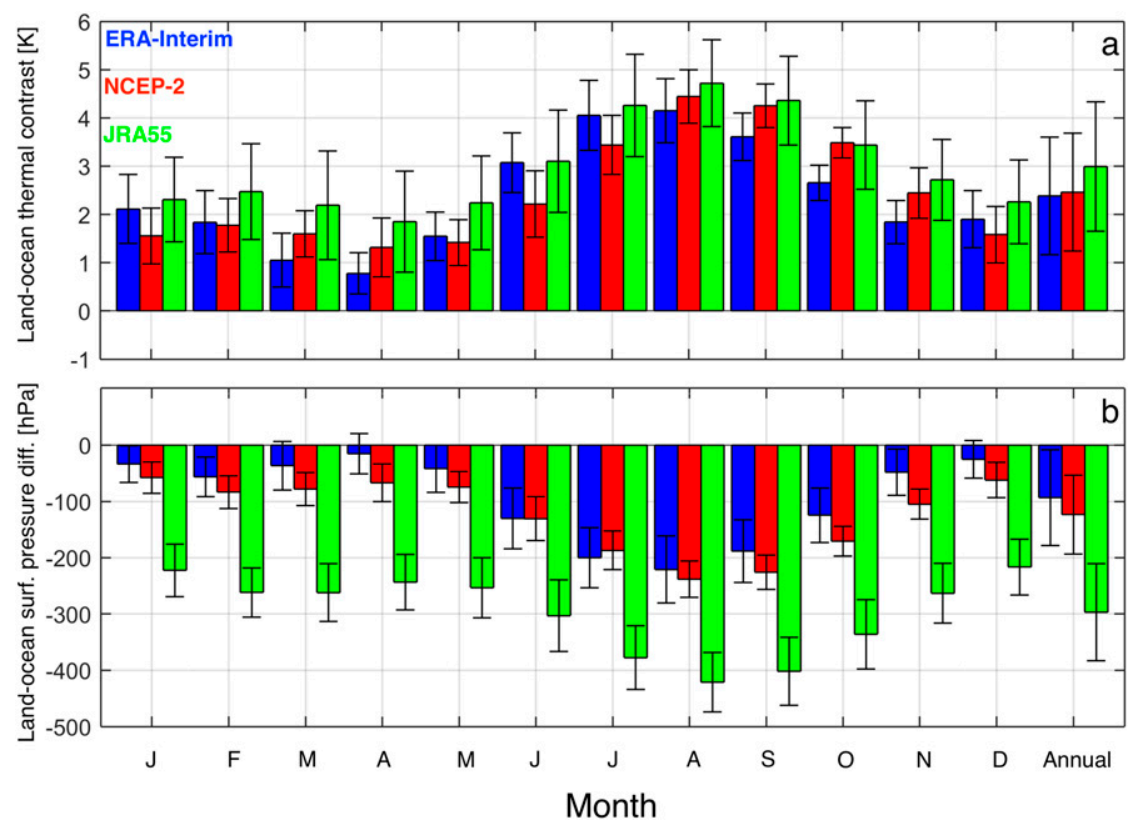

FIG. 2. Annual cycle of (a) near-surface land-ocean thermal contrast $\left(\Delta T_{\mathrm{ATL}} ; \mathrm{K}\right)$ and (b) zonal surface pressure gradient $\left(\Delta P_{\mathrm{ATL}} ; \mathrm{hPa}\right)$ between the central African landmass $\left(15^{\circ}\right.$ $\left.30^{\circ} \mathrm{E}, 5^{\circ} \mathrm{N}-5^{\circ} \mathrm{S}\right)$ and the equatorial Atlantic Ocean $\left(5^{\circ} \mathrm{W}-5^{\circ} \mathrm{E} ; 5^{\circ} \mathrm{N}-5^{\circ} \mathrm{S}\right)$ for the three reanalyses.

difference between the warm central African landmass and the cold equatorial eastern Atlantic (Fig. 2a and Fig. S11a in the online supplemental material). This suggests that the equatorial Atlantic SST may play a substantial role, through the land-ocean thermal contrast $\Delta T_{\mathrm{ATL}}$ (more details are given in section 3d), inconsistent with Cook and Vizy (2016). Cook and Vizy (2016) assumed that variations of equatorial Atlantic SST are not associated with the interannual variability in the strength of this low-level circulation. Schneider and Lindzen (1977) showed that a meridional sea surface temperature gradient drives a shallow meridional circulation below $800 \mathrm{hPa}$. However, for Neupane (2016) the land-ocean temperature difference controlled only the lower branch (low-level westerly jet) from July to September, whereas for Pokam et al. (2014) the lower branch (low-level westerly jet) is driven by the land-ocean adiabatic heating difference. So, in agreement with Schneider and Lindzen (1977), we presume that the near-surface land-ocean thermal contrast drives the Congo basin cell. Noteworthy is that, over central Africa, the Congo basin cell emerges as a key feature of the regional-scale circulation in the lower troposphere, year round (Figs. S6-S8 in the online supplemental material). This indicates that the annual cycle of the regional-scale zonal circulation over central Africa is inconsistent with Neupane (2016) and Cook and Vizy (2016), who respectively argued that the presence of a zonal shallow overturning cell over central Africa occurs only from July to September or from June to October.

\section{2) INTENSITY (STRENGTH) OF THE CONGO BASIN CELL: THE ANNUAL CYCLE}

The seasonal evolution of the Congo basin cell as well as the associated zonal mass-weighted streamfunctions are consistent in all three reanalyses (Figs. S6-S8). To describe the temporal and spatial evolution of Congo basin cell, we calculated the intensity and its associated longitudinal (zonal) position. To avoid spurious trends linked to the choice of a single and arbitrary pressure level, we vertically averaged the mass-weighted streamfunction between 925 and $850 \mathrm{hPa}$ and found the maximum and its corresponding zonal location $\left(\phi_{S}\right)$, respectively. The choice of 925 and $850 \mathrm{hPa}$ is made because throughout the lower troposphere (Figs. S6-S8) the mass-weighted streamfunction shows up at its maximum (it is actually a minimum because the massweighted streamfunction is negative) between these two pressure levels. The climatological annual mean intensity of the Congo basin cell and its location are $-74.79 \pm 43.13 \mathrm{~Sv}$ at $12.48^{\circ} \pm 2.64^{\circ} \mathrm{E}$ for ERAInterim, $-67.01 \pm 34.59 \mathrm{~Sv}$ at $14.14^{\circ} \pm 4.85^{\circ} \mathrm{E}$ for NCEP-2, and $-78.28 \pm 43.68 \mathrm{~Sv}$ at $12.61^{\circ} \pm 3.80^{\circ} \mathrm{E}$ for JRA-55. The annual cycle of the Congo basin cell indicates that in November (Figs. 3a-c and Figs. S6-S8) the Congo basin cell starts to develop and that it increases slightly in 

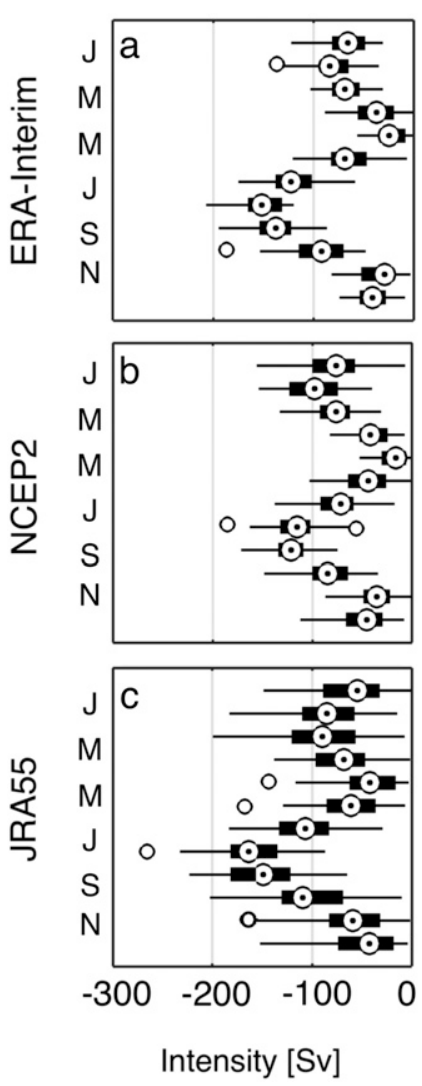
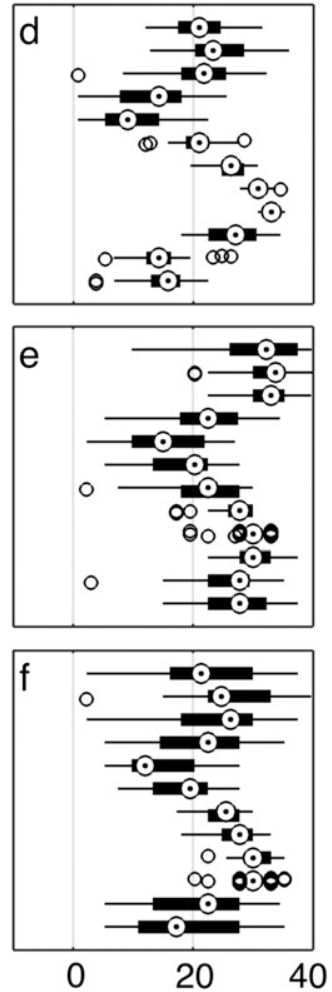

Width [deg. east]
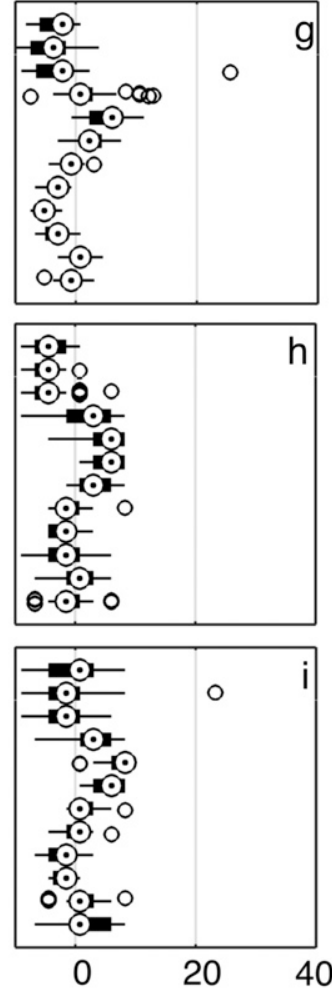

Western Edge [deg. east]
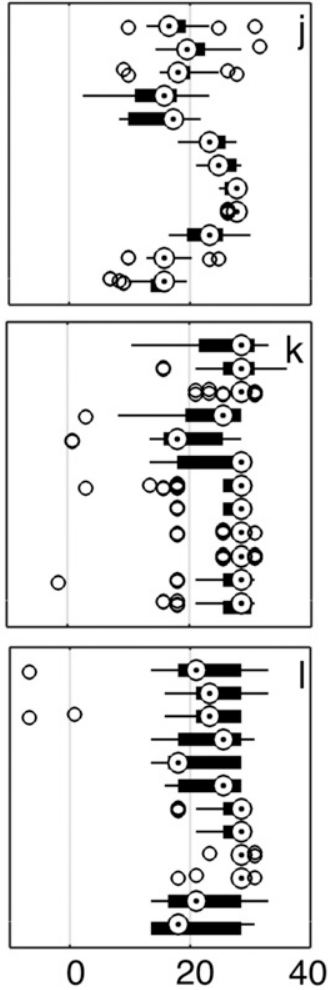

Eastern Edge [deg. east]

FIG. 3. Annual cycle of Congo basin cell (a)-(c) intensity, (d)-(f) width, and (g)-(i) western and (j)-(l) eastern (Congo Air Boundary) edges for (top) ERA-Interim, (middle) NCEP-2, and (bottom) JRA-55.

February and then decreases a month later to reach its minimum in May, with a value of $-12.71 \pm$ $22.26 \mathrm{~Sv},-4.68 \pm 24.22 \mathrm{~Sv}$, and $-25.32 \pm 41.29 \mathrm{~Sv}$ for ERA-Interim, NCEP2, and JRA-55, respectively (Figs. 3a-c). From July to October, the Congo basin cell widens and strengthens before peaking in August, with maximum values of $-152.68 \pm 23.74 \mathrm{~Sv}$ and $-160 \pm$ 28.20 Sv for ERA-Interim and JRA-55 respectively, and in September, for NCEP-2, with $-121.89 \pm 39.12 \mathrm{~Sv}$ (Figs. 3a-c). This is followed by a sudden decrease of Congo basin cell intensity until November (Figs. 3a-c and Figs. S6-S8). The intensification of the Congo basin cell is larger when the land-ocean thermal contrast is higher (Figs. 2a and 3a-c). The annual cycle of Congo basin cell intensity shows higher amplitude widely spread in JRA-55 than in ERA-Interim and NCEP-2 (Figs. 3a-c). From April to October the Congo basin cell intensity is stronger in NCEP2 and has the same sign as ERA-Interim, whereas from November to March NCEP2 shows weaker intensity and opposite sign (Fig. S9a in the online supplemental material). For JRA-55, the intensity is weaker from March to May and in August, September, and November (Fig. S9a). From
December to February, and in June and July, the Congo basin cell is stronger in JRA-55 than in ERA-Interim but with the same sign (Fig. S9a). This seasonal uncertainty in reanalyses may be due to their different responses to seasonal near-surface temperature forcing.

\section{3) The SEAsonality of THE CONGO BASIN CELL WIDTH}

To diagnose the Congo basin cell width (zonal extent), we determine the longitude where $\psi=0$ (i.e., the longitude at which the zonal mass-weighted streamfunction changes sign). To do so, we vertically averaged the massweighted streamfunctions between 1000 and $850 \mathrm{hPa}$ before estimating the western and eastern edge longitudes, respectively. The difference between the two edge longitudes indicates the width or zonal extent of the Congo basin cell. The western edge longitude gives insight into the location from where the water vapor and heat transport originate and the eastern edge longitude indicates how far the water vapor and heat can be transported toward central Africa inland. Also, the eastern edge longitude is the position of the convergence zone where the low-level jets originated from the 


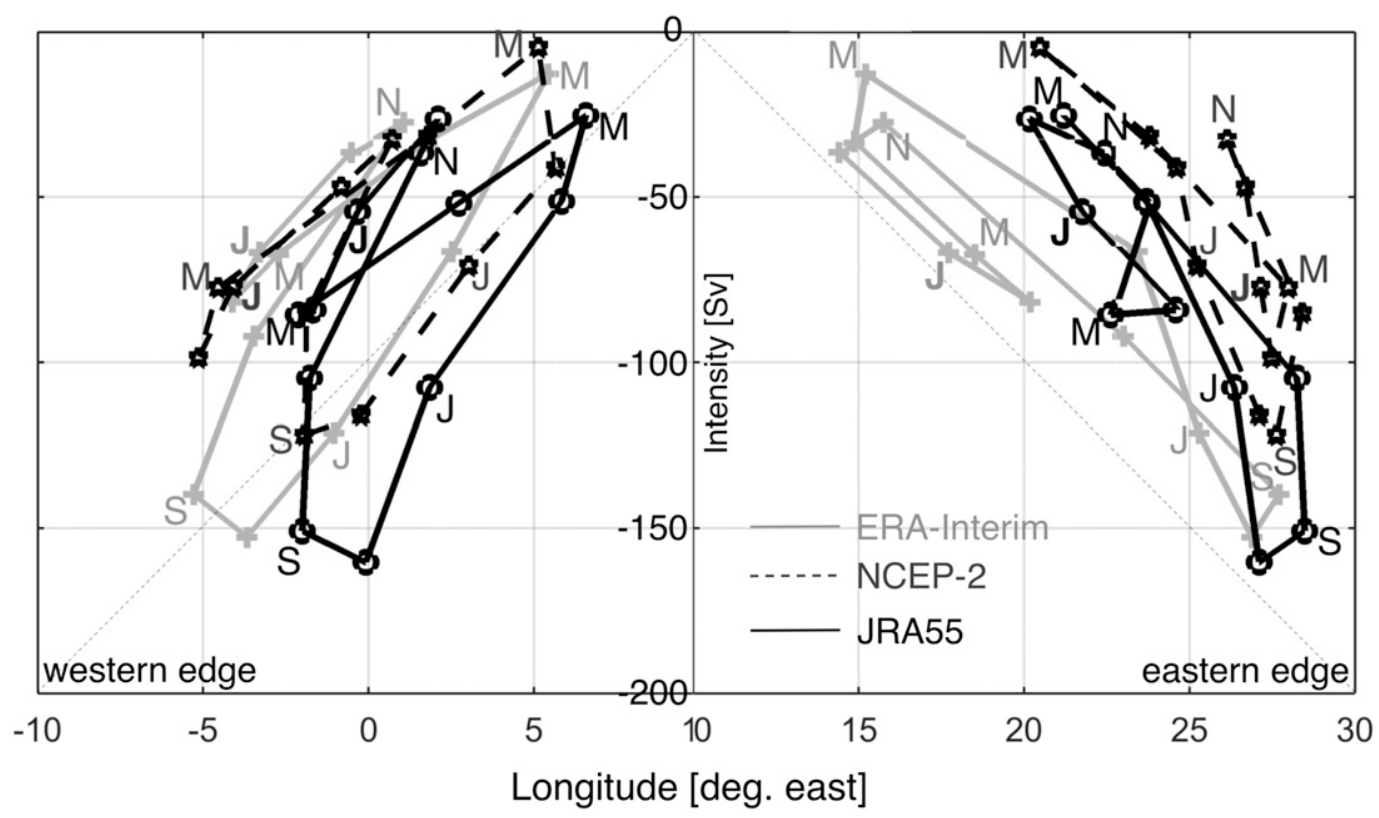

FIG. 4. Annual cycle of Congo basin cell intensity (Sv) vs (left) western and (right) eastern (Congo Air Boundary) edges (degrees of longitude).

equatorial Atlantic and, crossing the central African landmass, met the Indian monsoon system. Actually, the eastern edge longitude could be also called the Congo Air Boundary (Nicholson 1996; Tierney et al. 2011). Thus, the Congo Air Boundary is associated with the rising branch position of the Congo basin cell, whereas the western edge longitude is associated with the subsiding branch. The Congo basin cell width may also indicate the path of the water vapor and heat transport into the central African interior. The climatological annual mean of Congo basin cell width ranges between $26.17^{\circ} \pm 7.76^{\circ}$ longitude in NCEP-2 and $21.35^{\circ} \pm 8.25^{\circ}$ longitude in ERA-Interim (Figs. 3d-f and Figs. S6-S8). Examining the annual cycle of the edge longitudes, we find out that the two edge longitudes vary out of phase with each other, with larger annual cycle amplitude at the western edge than at the Congo Air Boundary, particularly in NCEP-2 and JRA-55 (Figs. 3g-1 and 4). On the other hand, the bimodal signal of the Congo basin cell intensity is similar to that of the western edge longitude (Figs. 3a-c,g-i), whereas the annual cycle of Congo basin width is similar to that of the Congo Air Boundary (Figs. 3d-f,j-l). However, the difference in reanalyses shows the same sign in widening of the Congo basin cell in NCEP2, JRA-55, and ERA-Interim. The widening of the Congo basin cell is higher in NCEP2 than in JRA-55 and occurs when the land-ocean thermal contrast is weaker (Fig. 2a and Fig. S9b). Moreover, when the land-ocean thermal contrast is higher, the
Congo basin cell narrows more in NCEP2 and JRA-55 than in ERA-Interim (Fig. 2a and Fig. S9b). The widening of the Congo basin cell in NCEP2 and JRA-55 is associated simultaneously with the westward movement of the western edge and the eastward elongation of the Congo Air Boundary (Fig. 2a and Figs. S9c,d).

Furthermore, there is a strong relationship between the seasonal Congo basin cell intensity and width (Fig. S10 in the online supplemental material), meaning that widening of the Congo basin cell is strongly dependent on its intensity. We also plotted in Fig. 4 the Congo basin cell intensity versus its width to understand their seasonality. The maximum intensity and width of the Congo basin cell occur when the cold, moist air is transported from a farther west position in the equatorial Atlantic, particularly during January-March (JFM) and July-September (JAS) (Figs. 3 and 4 and Figs. S5S8). However, the temperature and water vapor are lower in JAS than in JFM (Fig. S5) because of the occurrence of the cold-tongue SST over the equatorial Atlantic (Richter et al. 2012; Tokinaga and Xie 2011). At the same time, the Congo Air Boundary seems to be stuck at around $28^{\circ} \mathrm{E}$, in all reanalyses (Figs. 3 and 4 and Fig. S9d). In April-June (AMJ) and OctoberDecember (OND), there is an eastward stretch of the western edge longitude, reducing the path of cold and moist air transport to the central African interior (Figs. 3 and 4 and Figs. S4 and S9c). Simultaeously, the Congo Air Boundary moves in an opposite direction than its 

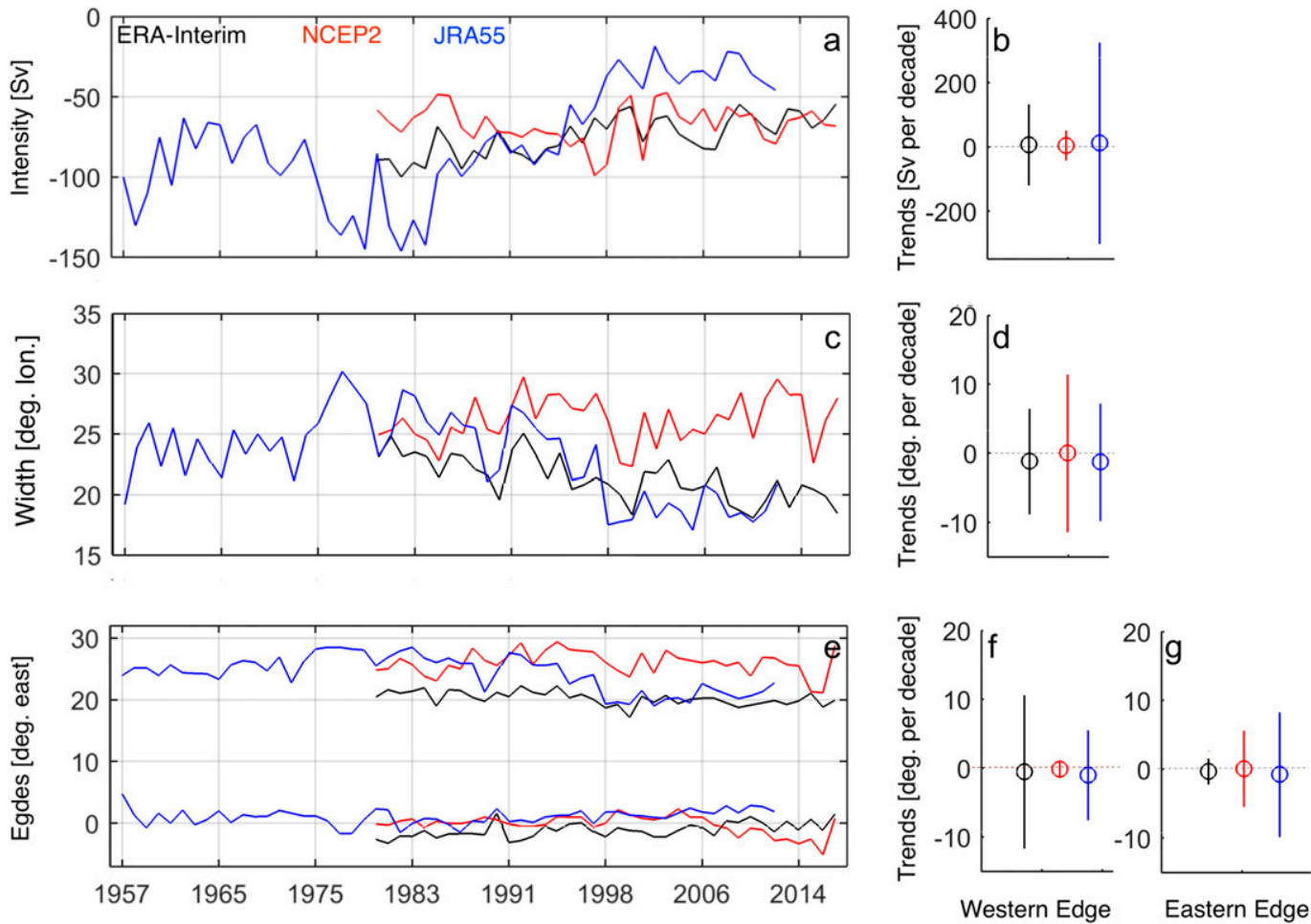

FIG. 5. Time series of the annual mean of Congo basin cell (a) intensity (Sv), (c) width (deg. lon.), and (e) western and eastern (Congo Air Boundary) edge (degrees of longitude) for ERA-Interim (black), NCEP-2 (red), and JRA55 (blue). (b),(d),(f),(g) The corresponding linear trends, with the vertical bar representing the interval of confidence.

western counterpart edge longitude (Figs. 3 and 4). The most basic feature that emerges is that the maximum of both intensity and width occurs in August/September, whereas the minimum of both intensity and width occurs in May, with no evident bimodality in any of the three reanalyses (Fig. 4). This highlights that the farther away the cold, moist air comes from, the farther it will be transported into the central African interior, and the stronger and wider the Congo basin cell will be (Figs. 3 and 4 and Figs. S5-S8). While the Congo basin cell is weaker and narrowed, the path of the cold, moist air transport is shorter. This transport path is larger in NCEP-2 and JRA-55 than in ERA-Interim (Figs. 3 and 4 and Figs. S6-S8). Note that when the equatorial circulation is supposed to be driven by the divergent component of the zonal wind there is no Congo Air Boundary over central Africa but this convergence zone, at low levels, is located at $40^{\circ} \mathrm{E}$ (over East Africa; Figs. S1 and S2). In addition, the majority of the transported water vapor into the central African landmass seems to originate from the western equatorial Atlantic (Fig. S8). This means that the monsoon-like circulation from equatorial Indian Ocean is prevented from transporting water vapor farther into the central Africa landmass. This is contrary to Dyer et al. (2017), who found that the Indian Ocean rather than the Atlantic Ocean is one of the main moisture sources for central Africa.

\section{4) INTERANNUAL VARIABILITY AND LONG-TERM TREND OF THE CONGO BASIN CELL}

Figure 5 shows the variability of the annual-mean Congo basin cell intensity, width, and its associated edge longitudes for ERA-Interim, NCEP-2, and JRA-55. There is a good degree of consistency in the variability of the Congo basin cell between ERA-Interim and JRA55, as suggested by their strong correlations (Fig. 5). But NCEP-2 seems to not reproduce realistically the interannual variability of the Congo basin cell, as indicated by its weak relationship with ERA-Interim and JRA-55 (Fig. 5). This shortcoming does appear again when analyzing the linear trends of Congo basin cell strength, width, and edge longitudes. The Congo basin cell intensification, with a trend of 8.03 and $14.14 \mathrm{~Sv}$ per decade (Fig. 5b), is associated with its narrowing, of $-1.13^{\circ}$ and $-1.14^{\circ}$ longitude per decade for the period 1979-2017 for ERA-Interim and 1958-2012 for JRA-55, respectively (Fig. 5d). For NCEP-2, there is 
somehow no intensification of the Congo basin cell ( $\sim 0.1 \mathrm{~Sv}$ per decade) during the 1979-2017 period (Fig. 5b), which is associated with a widening of $0.34^{\circ}$ longitude per decade in the same period (Fig. 5d). The narrowing of the Congo basin cell may be due to the westward shift of the Congo Air Boundary $\left(-1.04^{\circ}\right.$ longitude per decade) in JRA-55, whereas in ERAInterim it is due to the tendency of both western and eastern edge longitudes to migrate in opposite directions, by $0.63^{\circ}$ and $-0.50^{\circ}$ longitude per decade, respectively (Figs. 5e,f). In NCEP-2, the extension of the Congo basin cell is due mainly to the westward excursion of the western edge longitude $\left(-0.58^{\circ}\right.$ longitude per decade) with slight movement of the Congo Air Boundary $\left(-0.18^{\circ}\right.$ longitude per decade; Figs. 5e and 5f). Overall, the linear trend of the Congo basin cell may be more explained by the near-surface warming during our study period than by the land-ocean thermal contrast (Table S1 and Fig. S11b in the online supplemental material). Indeed, the near-surface warming occurs relatively more over the central African landmass than over the Atlantic Ocean, while there is no increase of the land-ocean thermal contrast in all reanalyses (Table S1 and Figs. S11a,b). On the other hand, the narrowing of the Congo basin cell is due to the surface warming happening at the Congo Air Boundary and the subsiding branch (over the equatorial Atlantic Ocean), respectively.

\section{b. Role of SST on regional-scale zonal circulation over central Africa}

Cook and Vizy (2016) assumed that variation of equatorial Atlantic SST is not associated with the interannual variability in the strength of the circulation. To test this hypothesis and support the results presented above in previous sections, we made use of the ECHAM5.3 experiments, which are forced with the observed global SSTs. The capability of ECHAM5.3 to capture the seasonality and interannual variability of the central Africa "pseudo" Walker cell and the Congo basin cell particularly in isobaric coordinates is evident (Fig. S12 in the online supplemental material). In ECHAM5.3, the Congo basin cell is stronger and wider than in reanalyses (Figs. S12 and S13a,c in the online supplemental material). However, the Congo basin cell slowed down $(-0.96 \mathrm{~Sv}$ per decade $)$ and widened $\left(0.51^{\circ}\right.$ longitude per decade) for the 1979 to 2012 period, similar to NCEP-2 (Figs. 5b,d). In addition, the near-surface land-ocean thermal contrast associated with the low surface pressure gradient is also well represented in ECHAM5.3, but the amplitude is relatively stronger than in all reanalyses (Fig. S14a,b in the online supplemental material).
The reproduction of all features of the regional-scale zonal atmospheric circulation in ECHAM5.3 over central Africa substantiates the key role played by the SST, inconsistent with Cook and Vizy (2016). Because the Congo basin cell is a thermally direct circulation, any increase of the near-surface land-ocean thermal contrast $\left(\Delta T_{\mathrm{ATL}}\right)$ may influence the Congo basin cell intensity and width (Fig. 6), while at midlevels $(\sim 700 \mathrm{hPa})$ it weakens the easterly jet (Fig. 7). The weakening of the midlevel easterly jet over central Africa is associated with its northward shifting from June to September (Fig. S15 in the online supplemental material). During this season (June-September), one can easily see the formation and development of the midlevel easterly jet in the Southern Hemisphere (south of the equator), but with relatively less magnitude than that in the Northern Hemisphere (Fig. S15). On the other hand, decreased $\Delta T_{\mathrm{ATL}}$ may lead to the opposite. For any change of $1 \mathrm{~K}$ in $\Delta T_{\mathrm{ATL}}$, the Congo basin cell intensification ranges between $-19.21 \mathrm{~Sv}$ in NCEP-2 and $-33.21 \mathrm{~Sv}$ in JRA-55 (Figs. 6a-c) and -30.54 in ECHAM5.3 (Fig. 6j), while the reduction of the midlevel easterly jet ranges between 58.19Sv in NCEP2 and 92.96 Sv in JRA-55 and 63.70 Sv in ECHAM5.3 (Figs. 7a-c). In the same time, the widening of Congo basin cell occurs and ranges between $0.77^{\circ}$ longitude in NCEP-2 and $4.90^{\circ}$ longitude in ERA-Interim (Figs. 6d-f). The seasonality of the Congo basin cell width is related to its intensity (Fig. S10). Therefore, higher land-ocean thermal contrast strengthens the Congo basin cell, which in turn, flows farther inland, leading to the eastward extension of the Congo Air Boundary rather than to the zonal displacement of the western edge longitude (Figs. 6g-i). As a result of higher surface temperature variation over the equatorial Atlantic than over the central African landmass, the increased $\Delta T_{\mathrm{ATL}}$ generates a stronger surface pressure gradient $\Delta P_{\mathrm{ATL}}$, which in turn leads to a stronger and wider Congo basin cell and a reduced midlevel easterly jet (Fig. 7). This means that during the presence of cold-tongue SST over equatorial Atlantic in July-September (Richter et al. 2012; Tokinaga and Xie 2011), the induced stronger $\Delta P_{\mathrm{ATL}}$, from the increased $\Delta T_{\mathrm{ATL}}$, leads to larger advection of cold, relative dry air from the farther west position in the equatorial Atlantic toward the easternmost position of the Congo Air Boundary over the central African landmass (Figs. 2 and 6a-c and Figs. S5-S8). On the other hand, decreased $\Delta T_{\mathrm{ATL}}$ reduces $\Delta P_{\mathrm{ATL}}$, which leads to shorter advection of warm, moist air from the equatorial Atlantic toward the west-shifted position of the Congo Air Boundary (Figs. 2 and 6 and Figs. S5-S8). This results in a weaker and narrower Congo basin cell. Thus, the annual cycle of the Congo basin cell intensity, width, and its associated edge longitudes as well as the midlevel easterly jet are all controlled by the near-surface land-ocean thermal contrast, through the zonal surface pressure gradient. In 


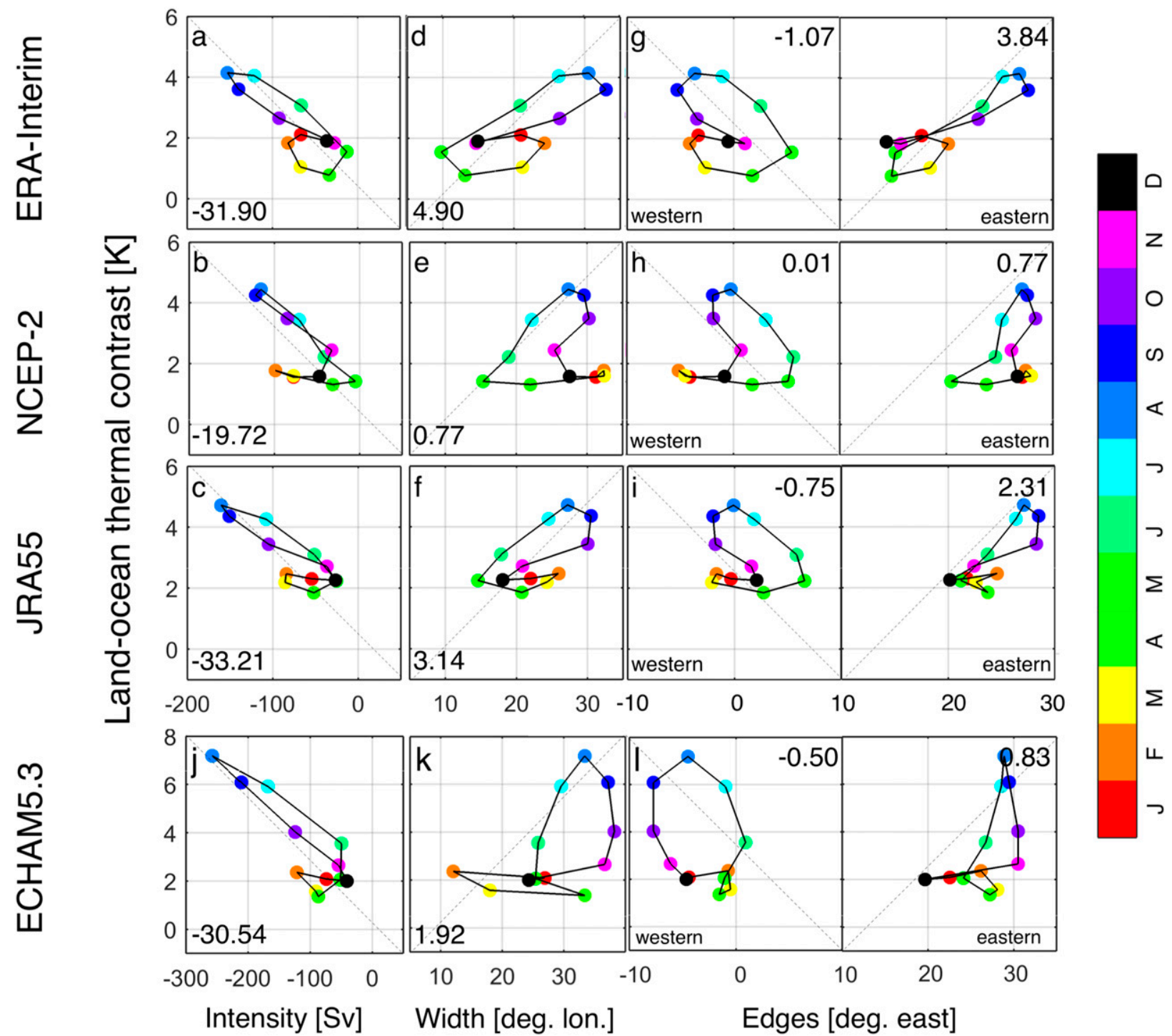

FIG. 6. Annual cycle of the near-surface land-ocean thermal contrast $\left(\Delta T_{\mathrm{ATL}} ; \mathrm{K}\right)$ vs Congo basin cell (a)-(c) intensity (Sv), (d)-(f) width (deg. lon.), and (g)-(i) western and eastern edge ( $\left.{ }^{\circ} \mathrm{E}\right)$ for (top) ERA-Interim, (middle) NCEP-2, and (bottom) JRA-55. In each panel, the number represents the response of the intensity, width, and longitude edges to $\Delta T_{\mathrm{ATL}}$. (j)-(l) The corresponding cycles for ECHAM5.3 (note that some panels have differing scales).

addition, the opposite sign in the relationship between $\Delta T_{\mathrm{ATL}}$ and both the edge longitudes (Figs. 6g-i,l) may explain the out-of-phase behavior of both Congo basin cell edge longitudes.

\section{c. Relationship between Congo basin cell and local rainfall}

No significant correlation is found between the Congo basin cell and local rainfall (Figs. S16a-c in the online supplemental material), consistent with Neupane (2016). However, the annual cycle of the zonal rainfall maximum position is modulated by the width of the Congo basin cell, which in turn is controlled by the zonal surface pressure gradient $\left(\Delta P_{\mathrm{ATL}}\right)$ through the near-surface land-ocean thermal contrast $\left(\Delta T_{\mathrm{ATL}}\right)$. Enhanced $\Delta P_{\mathrm{ATL}}$ may displace the zonal rainfall maximum toward Atlantic offshore region, while reduced $\Delta P_{\mathrm{ATL}}$ moves the zonal rainfall maximum eastward toward the Congo Air Boundary (Figs. S16d-f). This indicates an indirect mechanism linking the Congo basin cell to central African rainfall via regulation of the zonal rainfall maximum by induced $\Delta P_{\mathrm{ATL}}$.

The longitudinal variation of rainfall shows double maxima over the central African landmass, separated by a slight drying at the position of the Congo basin cell (Fig. 1 and 

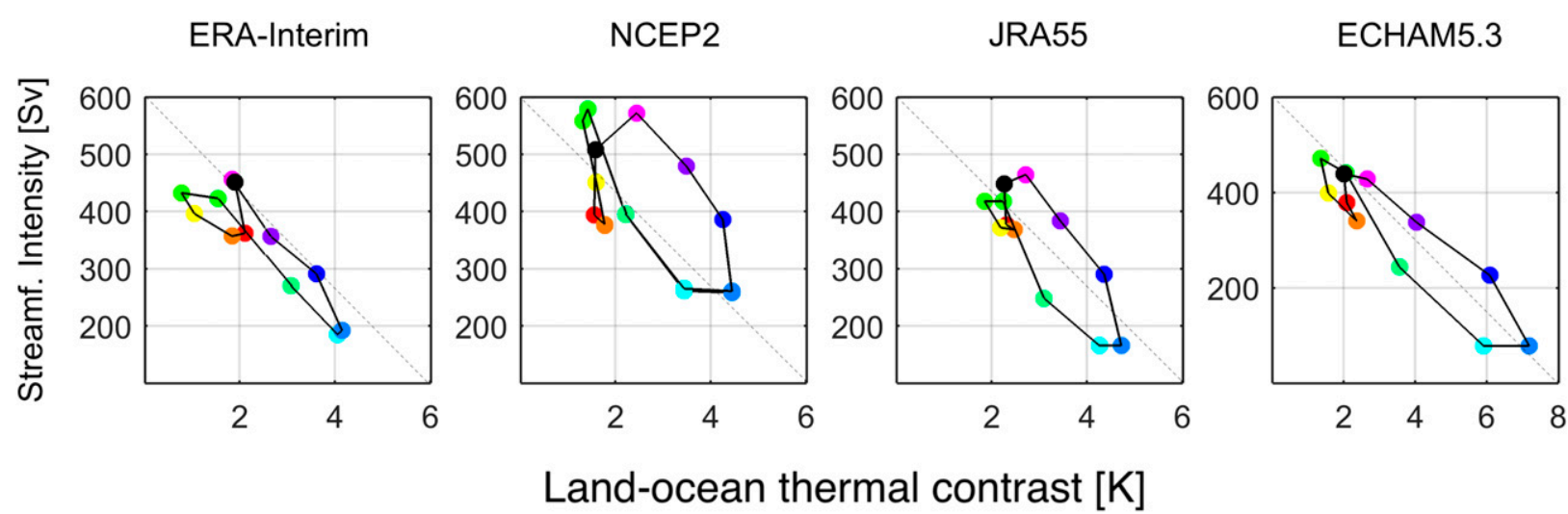

\section{Land-ocean thermal contrast $[\mathrm{K}]$}

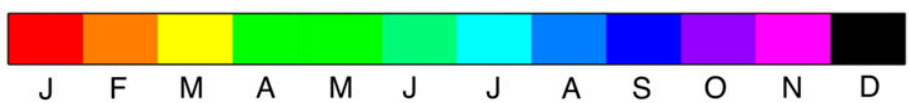

FIG. 7. As in Fig. 6, but for streamfunctions averaged at midlevels ( $700-600 \mathrm{hPa})$ between $15^{\circ}$ and $30^{\circ} \mathrm{E}$ over central Africa.

Figs. S6-S8). High rainfall $\left(>4 \mathrm{mmday}^{-1}\right)$ is associated with a weaker and narrower Congo basin cell and stronger midlevel easterly jet than during low rainfall, meaning that deep convection associated with a stronger midlevel easterly jet is timed out of phase with the expansion of the Congo basin cell (Fig. 3 and Fig. S17 in the online supplemental material). This suggests a dynamical process that may compensate the latent heat release associated with deep convection over central Africa. This leads us to assume that, despite atmospheric stability in lower troposphere $(\partial h / \partial z>0$; Fig. 8, right part of the panels), the atmospheric instability over central Africa is mainly due to the Congo basin cell, with its associated mass-weighted streamfunctions containing information about the vertical velocity of air parcels [see Eq. (4)]. In other words, the presence of the Congo basin cell is likely to destabilize the atmosphere over central Africa via a nonlinear mechanism. This physical mechanism is not reproduced when we assume that the atmosphere over central Africa is driven by a thermally divergent component of the zonal wind (Pokam et al. 2014; Yu and Zwiers 2010; Yu et al. 2012; Bayr et al. 2014; Cook and Vizy 2016). The vertical velocity $(\partial \psi / \partial p<0)$ associated with the mass-weighted streamfunctions computed with the divergent component of the zonal wind is inconsistent with the atmospheric stability $(\partial h / \partial z>0)$ prevailing in the lower troposphere over central Africa (Fig. S3 and Fig. 8, right part of the panels). ECHAM5.3 does reproduce very well all of these physical processes.

\section{d. Overview of the regional-scale meridional circulation over central Africa}

Peixoto and Oort (1992) argued that a zonal land-ocean thermal contrast is likely to induce a shallow meridional circulation via the thermal wind relation. To investigate this mechanism over central Africa, we compute the meridional mass-weighted streamfunctions (averaged between $15^{\circ}$ and $30^{\circ} \mathrm{E}$ ) as defined by Nguyen et al. (2013), Stachnik and Schumacher (2011), and Oort and Yienger (1996) and show its annual cycle in Fig. 8 for JRA-55 (for NCEP-2, ERAInterim, and ECHAM5.3, see Figs. S18-S20 in the online supplemental material). Strong symmetric overturning (Hadley) cells are found over central Africa, with the ascending branch migrating from $15^{\circ} \mathrm{S}$ in January to $15^{\circ} \mathrm{N}$ in July/August and sinking branch at midlatitudes (Fig. 8). From August to December, the Hadley cells are moving backward (Fig. 8). Interestingly, from April/May to October, a strong anticlockwise Hadley cell encompasses the entire central African region (Fig. 8). At upper levels, the circulation is poleward, whereas at low levels the circulation is equatorward and converges essentially over the Sahel, located between $10^{\circ}$ and $20^{\circ} \mathrm{N}$ (Fig. 8). As a result of the zonal surface land-ocean contrast, the induced vertical meridional wind shear-characteristic of baroclinic flows-occurs at low levels between the surface and $850 \mathrm{hPa}$ (Fig. 8), depicting a shallow meridional overturning circulation year round as shown by the annual cycle (Fig. 8). Because Hadley cells are thermally direct circulations, the most striking feature is that rainfall maximum position over central Africa (Fig. 8, bottom part of the panels) is more determined by the ascending branch at the midlevels than near the surface where the temperature is higher than aloft year round. Indeed, the transported cross-equatorial water vapor warms up when it reaches the Sahel (between $10^{\circ}$ and $20^{\circ} \mathrm{N}$ ), where the lower tropospheric temperature is the warmest (Fig. S18). In addition, the atmospheric instability $(\partial h / \partial z<0)$ over central Africa, between 850 and $600 \mathrm{hPa}$ (Fig. 8, right part of the panels) is associated with the southward import of high moist static energy $h$, through the 


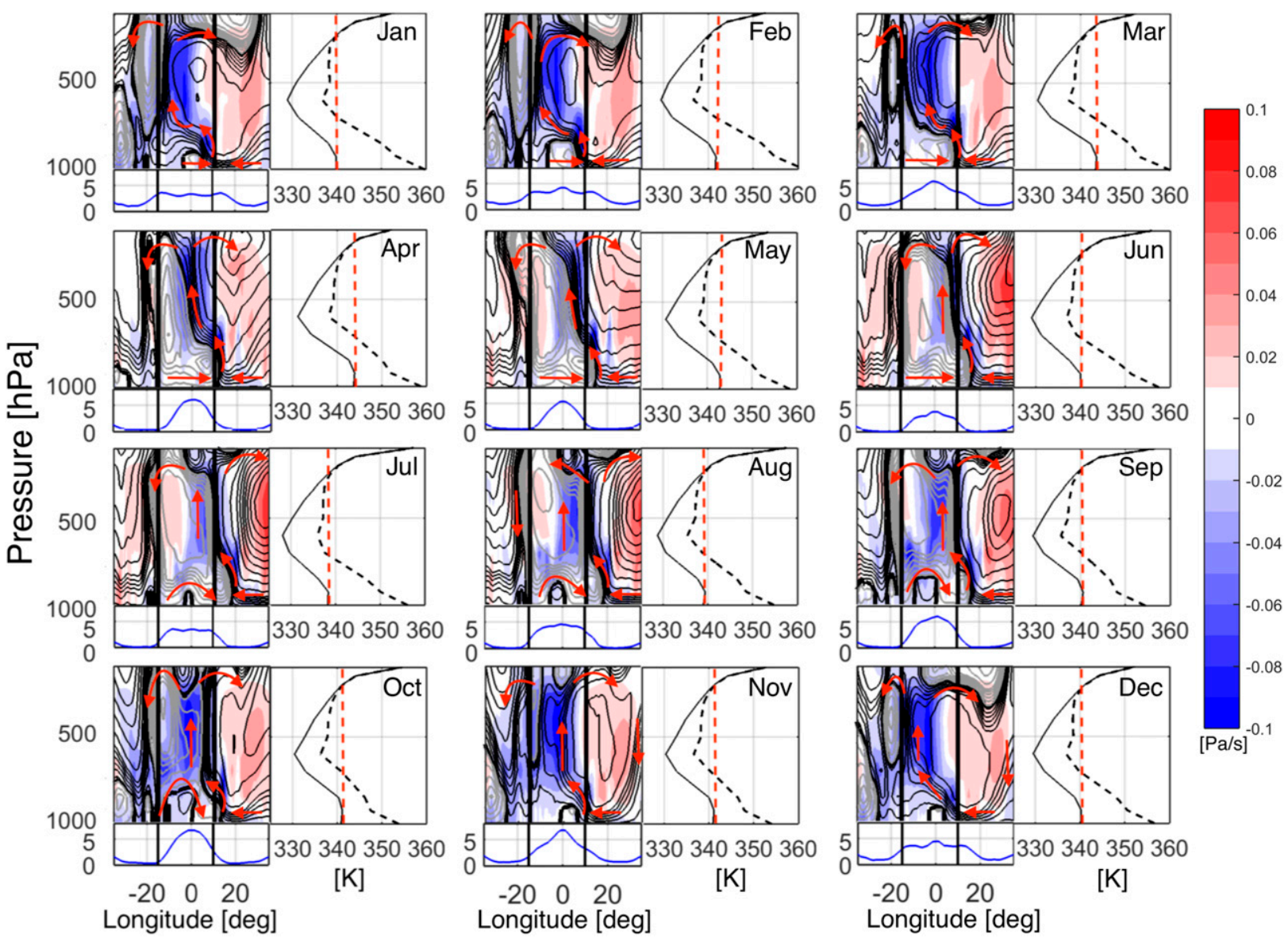

FIG. 8. Annual cycle of the meridional mass-weighted streamfunctions (contours; Sv) and vertical velocity (shaded; Pa s ${ }^{-1}$ ), rainfall $\left(\mathrm{mm}\right.$ day ${ }^{-1}$; blue line, at the bottom of the panels), and the vertical profile of moist static energy averaged over central Africa $\left(15^{\circ}-30^{\circ} \mathrm{E}\right.$; $5^{\circ} \mathrm{N}-5^{\circ} \mathrm{S}$ ) (black solid line in the right part of the panels; K) and saturated moist static energy (black dashed line in the right part of the panels; K) over central Africa for JRA-55. Gray and black contours represent positive and negative values of mass-weighted streamfunctions. Contour intervals are $20 \mathrm{~Sv}$ between 5 and $100 \mathrm{~Sv} ; 75 \mathrm{~Sv}$ between 150 and $600 \mathrm{~Sv}$, and $150 \mathrm{~Sv}$ up of $700 \mathrm{~Sv}$. Black vertical bars represent the meridional limit of central Africa, and the red vertical dashed bar (in the right part of the panels) represents the value of the moist static energy near the surface $(1000 \mathrm{hPa})$.

strong positive Hadley cell (Fig. 8). At $\sim 700 \mathrm{hPa}$, the moist air saturates and initiates a deep convection (Fig. 8, dashed red line in the right part of the panels). It is this deep convection associated with the position of internal and latent heat energy maxima at midlevel that determines the annual cycle position of the rainfall maximum over central Africa (Fig. S18). ECHAM5.3 does represents very well the seasonal characteristics of the meridional shallow overturning circulation over central Africa as well as the vertical profile of moist static energy and the seasonality of rainfall maximum position (Fig. S20).

\section{e. Proposed mechanisms controlling the Congo basin cell formation}

To determine physical mechanisms responsible of the Congo basin cell formation and maintenance, we conduct a closer inspection of Figs. 1, 2, and 6-8 (and Figs. S5, S6, and S15 and Texts S2 and S3 in the online supplemental material). The schematic diagram of the proposed mechanism is summarized in Fig. 9. Throughout the year, the solar forcing warms up more central African landmass than surrounding oceans because of the heat capacity difference. This generates a near-surface land-ocean thermal contrast, particularly between the warm central African landmass and equatorial Atlantic $\left(\Delta T_{\mathrm{ATL}}\right)$. This $\Delta T_{\mathrm{ATL}}$ induces a quasi-permanent zonal surface pressure gradient $\left(\Delta P_{\mathrm{ATL}}\right)$ that triggers a monsoon-like circulation (step $1 \rightarrow 2$; Fig. 9). Notably, at low levels, stable atmosphere dominates over central Africa as indicated by positive atmospheric convective stability ( $\partial h / \partial z>0$; Fig. 8 , right part of the panels). Thus, to destabilize the atmosphere in the lower troposphere, a 


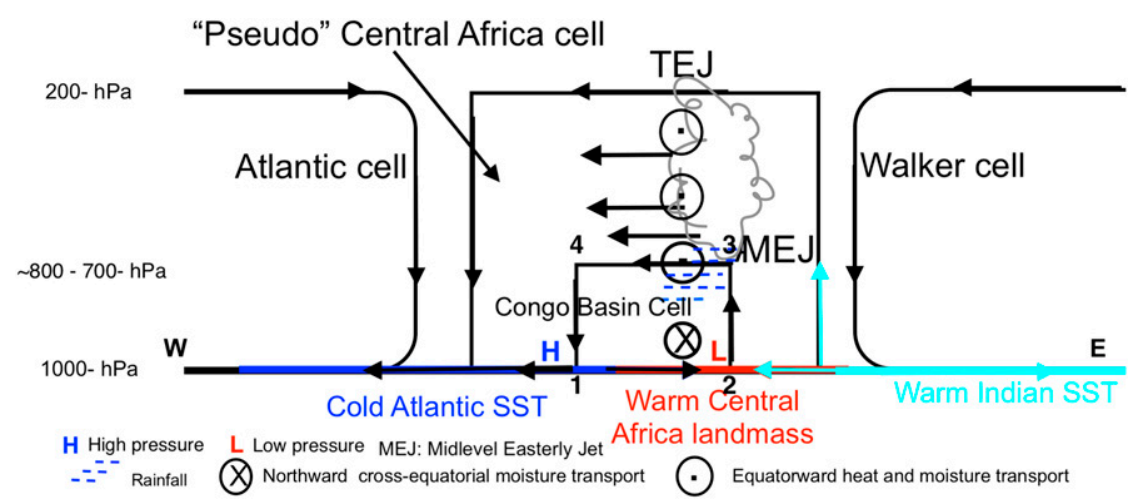

FIG. 9. Schematic diagram of the zonal large-scale circulation over central Africa and its surrounding oceans as proposed in this paper. The Congo basin cell acts a small heat engine, transporting latent and sensible heat from the warm central Africa landmass to the cold equatorial Atlantic, reminiscent of a mixed Carnot-steam cycle.

mass convergence builds up at the surface along the Congo Air Boundary resulting from the monsoon-like circulation at low levels. This allows the warm, moist air parcels to uplift vertically (Banacos and Schultz 2005). As a result of this nonlinear mechanism, the rise of unsaturated warm, moist air parcels (step $2 \rightarrow 3$; Figs. 9 and 8 , right panels) is associated with the adiabatic cooling, which leads to saturation and the release of latent heat (condensation) between 800 and $700 \mathrm{hPa}$ (red dashed line, cloud base; Fig. 8, right panels). Note that the latent heat release (see Text S2) is not an external energy, but it is associated with the internal energy conversion. Aloft at $800 \mathrm{hPa}$, the air parcel ascends moist adiabatically to reach stability at $\sim 200 \mathrm{hPa}$ (top of cloud; Fig. 8, right panels), indicative of deep convection. Moreover, the mechanical work associated with the low-level westerly jet may also indicates at which pressure level (altitude) the warm, moist air parcels could rise to saturate. This work output may determine the seasonal change over central Africa: a stronger low-level westerly transport (work output) associated with low energy content $(h<$ $340 \mathrm{~K}$ ) over the central African landmass should rise higher, causing the air parcel to saturate (e.g., in JJA; Fig. 8, right panels). This is suggestive of a shallow convection, leading to low rainfall season (Fig. S5, bottom panels). For high rainfall season $\left(>4 \mathrm{~mm} \mathrm{day}^{-1}\right)$, high energy content air parcels ( $h>340 \mathrm{~K}$, Fig. 8, right panels) over the central African landmass are associated with less work output of the low-level westerly jet so that the air parcels do saturate at a lower pressure level (altitude) than during low rainfall seasons. One can readily see that the convective updrafts depend on the underlying energy content of the air parcel (related to moist static energy at near surface; see Text S2) and the induced low-level westerly jet, controlled by $\Delta T_{\mathrm{ATL}}$ through $\Delta P_{\mathrm{ATL}}$ rather than the midlevel easterly jet (see Text S3). This is consistent with Vigaud et al. (2009) and Pokam et al. (2014), who argued that the low-level westerly jet deepens further convection over central Africa. Nevertheless, the midlevel easterly jet may be formed as a result of mechanical work (step $3 \rightarrow 4$; Fig. 9) to balance the latent heat release that occurs during the convective updrafts associated with the saturation [see Text S3, Pauluis and Mrowiec (2013), and Pauluis (2011)]. To test our hypothesis about this mechanism driving the seasonal evolution of the midlevel easterly jet over central Africa, we assessed the seasonal response of the midlevel easterly jet (defined as the areal average of the zonal wind between 700 and $600 \mathrm{hPa}$ over equatorial central Africa) to the vertical velocity $\omega$ at the same pressure levels and plotted it in Fig. 10. The vertical velocity does contain information about the mass-weighted streamfunctions [see Eq. (4)] and its negative value is associated with ascending motion of the air mass, describing very well the convection (Pauluis and Mrowiec 2013; Pauluis 2011). The relationship between the midlevel easterly jet and the vertical velocity is diagnosed from monthly mean over the reanalyses' seasonal cycle, and regressing the latter on the former yields a slope of $0.47 \mathrm{~m} \mathrm{~s}^{-1}$ per $\mathrm{Pa} \mathrm{s}^{-1}$ for ERA-Interim, which is almost of the same range as for NCEP2 $\left(0.41 \mathrm{~m} \mathrm{~s}^{-1}\right.$ per Pa s$\left.{ }^{-1}\right)$ (Figs. 10a,b). This slope is somewhat lower than $0.87 \mathrm{~m} \mathrm{~s}^{-1}$ per Pa s${ }^{-1}$ for JRA-55 (Fig. 10c). This means that the midlevel easterly jet is more sensitive to convection via vertical velocity perturbations (Figs. 10a-c). In the annual mean, the response of the midlevel easterly jet to convection in ERA-Interim resides at somewhat the same value as in JRA-55, while it is at lower value in NCEP2, consistent with stronger midlevel easterly jet associated with deeper convection (Figs. 10a-c). This result suggests that the physics that 
ERA-Interim

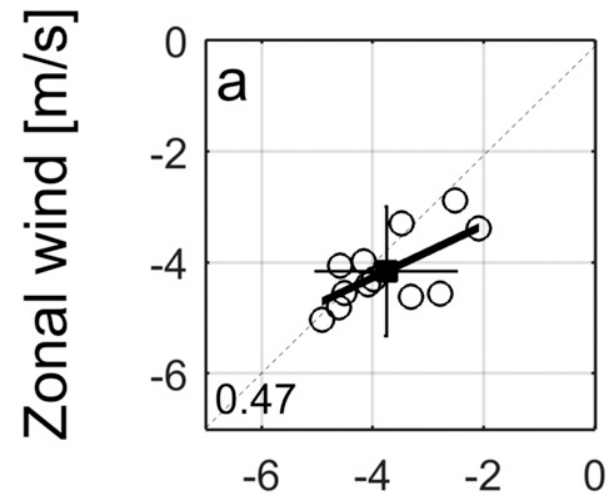

NCEP2

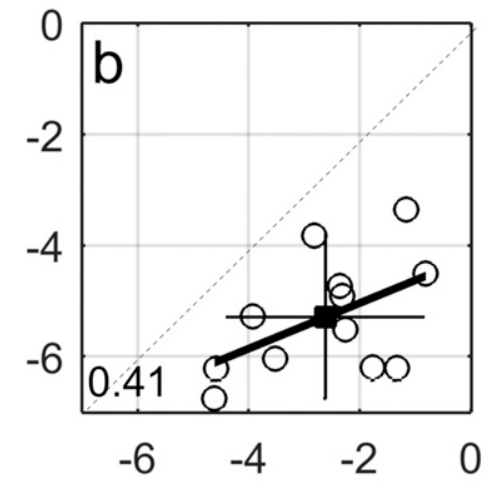

JRA55

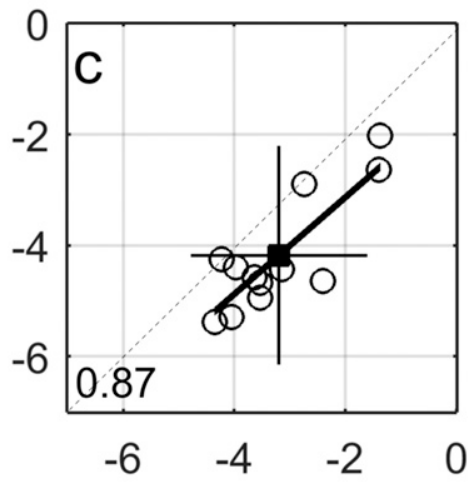

\section{Vertical velocity $[\mathrm{Pa} / \mathrm{s}]$}

FIG. 10. The seasonal response of the midlevel easterly jet defined as zonal wind averaged over equatorial central $\mathrm{Africa}\left(15^{\circ}-30^{\circ} \mathrm{E}, 5^{\circ} \mathrm{N}-5^{\circ} \mathrm{S}\right)$ and vertically averaged between 700 and $600 \mathrm{hPa}$ for (a) ERA-Interim, (b) NCEP-2, and (c) JRA-55. In (a)-(c), the number represents the response of the midlevel easterly jet to vertical velocity as a proxy of convection.

controls the seasonal cycle of the midlevel easterly jet via convection does not necessary control its variability at interannual time scale (Jackson et al. 2009; Chen 2005; Cook 1999; Thorncroft and Blackburn 1999). This shows that the seasonal evolution of the midlevel easterly jet did not play an important role to invigorate convection over equatorial central Africa (between $5^{\circ} \mathrm{S}$ and $5^{\circ} \mathrm{N}$ ) particularly, as speculated by Nicholson and Grist (2003). This finding confirms the crucial role played by Congo basin cell to induce an unstable atmosphere over central Africa. Thus, the Congo basin cell emerges as a key feature of the regional-scale circulation in the boundary layer, year round. Over the cold equatorial Atlantic Ocean, the saturated air mass subsides and leads to limited column water vapor and evaporation (step $4 \rightarrow 1$; Fig. 9).

According to the aforementioned thermodynamical mechanisms, the Congo basin cell transports both internal energy (temperature) and latent heat from the warm central African landmass to the cold equatorial Atlantic. In doing so, it acts as a small heat engine that produces mechanical work (transport) to sustain its shallow overturning circulation at low levels. The closed cycle that transports both latent and internal energies from warm to cold regions is known as a mixed Carnot-steam cycle (Pauluis 2011), with its efficiency depending essentially on the land-ocean thermal contrast between the warm central Africa landmass and the cold equatorial Atlantic and the moist static energy at near surface of the central African landmass. Although the mixed Carnot-steam cycle has been developed for hurricanes (Pauluis 2011), it actually presents a good framework to depict a closed shallow overturning cell as a small heat engine, with the heat extracted from surface through latent and internal energies. This framework provides good insight into the physical mechanisms explaining this key atmospheric feature over central Africa, particularly at low levels.

\section{Conclusions and discussion}

In this paper, we analyzed the thermodynamic processes associated with the zonal overturning circulation over central Africa and its adjoining oceans using reanalysis datasets and the atmospheric model ECHAM5.3. More specifically, we computed the zonal mass-weighted streamfunction, because it is commonly employed for its counterpart Hadley circulation to objectively define indices that help to describe formation, seasonal evolution, and variations of the regional-scale zonal circulation structure in terms of intensity and width. Many papers reported a zonal shallow overturning cell over central Africa. In this paper, however, we found the following:

1) Confined in the lower troposphere (between the surface and $800 \mathrm{hPa}$ ), a separated, single, closed, and counterclockwise zonal shallow overturning circulation that is thermally direct-namely, the Congo basin cell-persists throughout the year, with maximum intensity and width in August/September and minimum intensity and width in May, inconsistent 
with Neupane (2016). The Congo basin cell is a closed thermodynamic cycle that transports water vapor and temperature from the warm central African landmass to the cold eastern equatorial Atlantic, reminiscent of a mixed Carnot-steam engine (Pauluis 2011). The long trend of the Congo basin cell intensity and width is driven by the near-surface temperature warming on both the central African landmass and the eastern equatorial Atlantic rather than by the land-ocean thermal contrast between them.

2) The Congo Air Boundary is also a basic feature for the central African climate system in the manner that it allows the mass convergence to build up from the monsoon-like circulation at low levels, which in turn destabilizes the atmospheric stability at low levels by triggering an ascent motion of warm, moist air and leading to convection. The convection over central Africa is strongly associated with the mechanical work carried out by the low-level westerly jet and the moist static energy near the surface. However, the Congo basin cell does not play any crucial role in modulating the local rainfall over central Africa, but it may play an important role in rainfall redistribution over central Africa via the zonal rainfall maximum position.

3) The midlevel easterly jet is more sensitive to convection via vertical velocity perturbations. This suggests that the midlevel easterly jet formation may be due to the mechanical work that balances the latent heat release associated with convection (Pauluis and Mrowiec 2013; Pauluis 2011). This physics controlling the seasonal cycle of the midlevel easterly jet via convection does not necessary control its interannual variability (Nicholson and Grist 2003; Jackson et al. 2009; Chen 2005; Cook 1999; Thorncroft and Blackburn 1999).

4) The efficiency of the Congo basin cell determines the seasonal change of central Africa. This efficiency depends essentially on the land-ocean thermal contrast between the warm central African landmass and the cold equatorial Atlantic and the moist static energy near the surface of the central African landmass.

5) The rainfall maximum position over central Africa is more determined by the Hadley cell ascending branch at the midlevels than near the surface where the temperature is higher than aloft year round.

Acknowledgments. The authors thank the three anonymous reviewers for comments and suggestions. ECHAM5.3 experiments have been provided by Noel Keenlyside and Stephanie Gleixner. This study has been supported by the PREFACE project (EU FP7/20072013 under Grant Agreement 603521) and the National
Research Foundation SARChI Chair in OceanAtmosphere-Land Modelling and ACCESS project. The support from Nansen-Tutu Centre for Environmental Marine Research support is also appreciated.

\section{REFERENCES}

Asadullah, A., N. Mcintyre, and M. Kigobe, 2008: Evaluation of five satellite products for estimation of rainfall over Uganda. Hydrol. Sci. J., 53, 1137-1150, https://doi.org/10.1623/ hysj.53.6.1137.

Banacos, P. C., and D. M. Schultz, 2005: The use of moisture flux convergence in forecasting convective initiation: Historical and operational perspectives. Wea. Forecasting, 20, 351-366, https://doi.org/10.1175/WAF858.1.

Bayr, T., D. Dommenget, T. Martin, and S. Power, 2014: The eastward shift of the Walker circulation in response to global warming and its relationship to ENSO variability. Climate Dyn., 43, 2747-2763, https://doi.org/10.1007/s00382014-2091-y.

Bolvin, D. T., R. F. Adler, G. J. Huffman, E. J. Nelkin, and J. P. Poutiainen, 2009: Comparison of GPCP monthly and daily precipitation estimates with high-latitude gauge observations. J. Appl. Meteor. Climatol., 48, 1843-1857, https://doi.org/ 10.1175/2009JAMC2147.1.

Cabos, W., and Coauthors, 2017: The South Atlantic Anticyclone as a key player for the representation of the tropical Atlantic climate in coupled climate models. Climate Dyn., 48, 40514069, https://doi.org/10.1007/s00382-016-3319-9.

Chen, T. C., 2005: Maintenance of the midtropospheric North African summer circulation; Saharan high and African easterly jet. J. Climate, 18, 2943-2962, https://doi.org/10.1175/ JCLI3446.1.

Cook, K. H., 1999: Generation of the African easterly jet and its role in determining West African precipitation. J. Climate, 12, 1165-1184, https://doi.org/10.1175/1520-0442(1999)012<1165: GOTAEJ $>2.0 . \mathrm{CO} ; 2$.

, 2003: Role of continents in driving the Hadley cells. J. Atmos. Sci., 60, 957-976, https://doi.org/10.1175/1520-0469(2003) 060<0957:ROCIDT>2.0.CO;2.

, and E. K. Vizy, 2016: The Congo basin Walker circulation: Dynamics and connections to precipitation. Climate Dyn., 47, 697-717, https://doi.org/10.1007/s00382-015-2864-y.

Dee, D. P., and Coauthors, 2011: The ERA-Interim reanalysis: Configuration and performance of the data assimilation system. Quart. J. Roy. Meteor. Soc., 137, 553-597, https://doi.org/ 10.1002/qj.828.

Dezfuli, A. K., B. F. Zaitchik, and A. Gnanadesikan, 2015: Regional atmospheric circulation and rainfall variability in south equatorial Africa. J. Climate, 28, 809-818, https://doi.org/ 10.1175/JCLI-D-14-00333.1.

Donohoe, A., J. Marshall, D. Ferreira, and D. McGee, 2013: The relationship between ITCZ location and cross-equatorial atmospheric heat transport: From the seasonal cycle to the Last Glacial Maximum. J. Climate, 26, 3597-3618, https://doi.org/ 10.1175/JCLI-D-12-00467.1.

Dyer, E. L. E., D. B. A. Jones, J. Nusbaumer, H. Li, O. Collins, G. Vettoretti, and D. Noone, 2017: Congo Basin precipitation: Assessing seasonality, regional interactions, and sources of moisture. J. Geophys. Res., 122, 6882-6898, https://doi.org/ 10.1002/2016JD026240. 
Flohn, H., 1971: Tropical circulation patterns. Bonn. Meteor. Abh., 15, 1-55.

- - and H. Fleer, 1975: Climatic teleconnections with the equatorial Pacific and the role of ocean/atmosphere coupling. Atmosphere, 13, 96-109, https://doi.org/10.1080/ 00046973.1975 .9648391$.

Gleixner, S., N. S. Keenlyside, E. Viste, and D. Korecha, 2017: The El Niño effect on Ethiopian summer rainfall. Climate Dyn., 49, 1865-1883, https://doi.org/10.1007/S00382-0163421-Z.

Hua, W., L. Zhou, H. Chen, S. E. Nicholson, A. Raghavendra, and Y. Jiang, 2016: Possible causes of the central equatorial African long-term drought. Environ. Res. Lett., 11, 124002, https:// doi.org/10.1088/1748-9326/11/12/124002.

,,,,---- Y. Jiang, and A. Raghavendra, 2018: Understanding the central equatorial African long-term drought using AMIP-type simulations. Climate Dyn., 50, 1115-1128, https://doi.org/10.1007/s00382-017-3665-2.

$\longrightarrow,-$ _ S. E. Nicholson, H. Chen, and M. Qin, 2019: Assessing reanalysis data for understanding rainfall climatology and variability over central equatorial Africa. Climate Dyn., 53, 651-669, https://doi.org/10.1007/S00382-018-04604-0.

Huffman, G. J., R. F. Adler, D. T. Bolvin, and G. Gu, 2009: Improving the global precipitation record: GPCP version 2.1. Geophys. Res. Lett., 36, L17808, https://doi.org/10.1029/ 2009GL040000.

Jackson, B., S. E. Nicholson, and D. Klotter, 2009: Mesoscale convective systems over western equatorial Africa and their relationship to large-scale circulation. Mon. Wea. Rev., 137, 1272-1294, https://doi.org/10.1175/2008MWR2525.1.

Johnson, R. H., 2003: Thermal low. Encyclopaedia of Atmospheric Science, Academic Press, 2269-2273.

Kanamitsu, M., W. Ebisuzaki, J. Woollen, S.-K. Yang, J. J. Hnilo, M. Fiorino, and G. L. Potter, 2002: NCEP-DOE AMIP-II Reanalysis (R-2). Bull. Amer. Meteor. Soc., 83, 1631-1643, https://doi.org/10.1175/BAMS-83-11-1631.

Kobayashi, S., and Coauthors, 2015: The JRA-55 Reanalysis. J. Meteor. Soc. Japan, 93, 5-48, https://doi.org/10.2151/JMSJ.2015-001.

McCollum, J. R., A. Gruber, andM. B. Ba, 2000: Discrepancy between gauges and satellite estimates of rainfall in equatorial Africa. J. Appl. Meteor., 39, 666-679, https://doi.org/10.1175/ 1520-0450-39.5.666.

Mohino, E., S. Janicot, and J. Bader, 2011: Sahel rainfall and decadal to multi-decadal sea surface temperature variability. Climate Dyn., 37, 419-440, https://doi.org/10.1007/s00382-010 0867-2.

Neupane, N., 2016: The Congo Basin zonal overturning circulation. Adv. Atmos. Sci., 33, 767-782, https://doi.org/10.1007/s00376015-5190-8.

Nguyen, H., A. Evans, and C. Lucas, 2013: The Hadley circulation in reanalyses: Climatology, variability, and change. J. Climate, 26, 3357-3376, https://doi.org/10.1175/JCLI-D-12-00224.1.

Nicholson, S. E., 1996: A review of climate dynamics and climate variability in Eastern Africa. The Limnology, Climatology and Paleoclimatology of the East African Lakes, T. C. Johnson and E. O. Odada, Eds., Gordon and Breach, 25-56.

— , and J. P. Grist, 2003: The seasonal evolution of the atmospheric circulation over West Africa and equatorial Africa. J. Climate, 16,1013-1030, https://doi.org/10.1175/1520-0442(2003) 016<1013:TSEOTA > 2.0.CO;2.

Oort, A. H., and J. J. Yienger, 1996: Observed interannual variability in the Hadley circulation and its connection to
ENSO. J. Climate, 9, 2751-2767, https://doi.org/10.1175/15200442(1996)009<2751:OIVITH >2.0.CO;2.

Pauluis, O., 2011: Water vapor and mechanical work: A comparison of Carnot and steam cycles. J. Atmos. Sci., 68, 91-102, https://doi.org/10.1175/2010JAS3530.1.

- , and A. Mrowiec, 2013: Isentropic analysis of convective motions. J. Atmos. Sci., 70, 3673-3688, https://doi.org/10.1175/ JAS-D-12-0205.1.

Peixoto, J. P., and A. H. Oort, 1992: Physics of Climate. American Institute of Physics, $520 \mathrm{pp}$.

Pokam, W. M., L. A. T. Djiotang, and F. K. Mkankam, 2012: Atmospheric water vapor transport and recycling in equatorial Central Africa through NCEP/NCAR reanalysis data. Climate Dyn., 38, 1715-1729, https://doi.org/10.1007/s00382011-1242-7.

, C. L. Bain, R. S. Chadwick, R. Graham, D. J. Sonwa, and F. M. Kamga, 2014: Identification of processes driving lowlevel westerlies in west equatorial Africa. J. Climate, 27, 42454262, https://doi.org/10.1175/JCLI-D-13-00490.1.

Richter, I., S.-P. Xie, A. T. Wittenberg, and Y. Masumoto, 2012: Tropical Atlantic biases and their relation to surface wind stress and terrestrial precipitation. Climate Dyn., 38, 985-1001, https://doi.org/10.1007/s00382-011-1038-9.

Roeckner, E., and Coauthors, 2003: The atmospheric general circulation model ECHAM5-Part I: Model description. Max-Planck Institut für Meteorologie Tech. Rep. 349, 127 pp.

Schneider, E. K., and R. S. Lindzen, 1977: Axially symmetric steady-state models of the basic state for instability and climate studies. Part I. Linearized calculations. J. Atmos. Sci., 34, 263-279, https://doi.org/10.1175/1520-0469(1977)034<0263: ASSSMO $>2.0 . \mathrm{CO} ; 2$.

Siam, M. S., M.-E. Demory, and E. A. B. Eltahir, 2013: Hydrological cycles over the Congo and Upper Blue Nile basins: Evaluation of general circulation model simulations and reanalysis products. J. Climate, 26, 8881-8894, https://doi.org/ 10.1175/JCLI-D-12-00404.1.

Sperber, K. R., H. Annamalai, I. S. Kang, A. Kitoh, A. Moise, A. Turner, B. Wang, and T. Zhou, 2013: The Asian summer monsoon: An intercomparison of CMIP5 vs. CMIP3 simulations of the late 20th century. Climate Dyn., 41, 2711-2744, https://doi.org/10.1007/s00382-012-1607-6.

Stachnik, J. P., and C. Schumacher, 2011: A comparison of the Hadley circulation in modern reanalyses. J. Geophys. Res., 116, D22102, https://doi.org/10.1029/2011JD016677.

Suzuki, T., 2011: Seasonal variation of the ITCZ and its characteristics over central Africa. Theor. Appl. Climatol., 103, 3960, https://doi.org/10.1007/s00704-010-0276-9.

Thorncroft, C. D., and M. Blackburn, 1999: Maintenance of the African easterly jet. Quart. J. Roy. Meteor. Soc., 125, 763-786, https://doi.org/10.1002/qj.49712555502.

Thorsten, P., and M. Richter, 2014: The atmospheric circulation. Tropical Forestry Handbook, L. Pancel and M. Köhl, Eds., Springer, 303-331.

Tierney, J. E., J. M. Russell, J. S. S. Damsté, Y. Huang, and D. Verschuren, 2011: Late Quaternary behavior of the East African monsoon and the importance of the Congo Air Boundary. Quat. Sci. Rev., 30, 798-807, https://doi.org/ 10.1016/j.quascirev.2011.01.017.

Tokinaga, H., and S.-P. Xie, 2011: Weakening of the equatorial Atlantic cold tongue over the past six decades. Nat. Geosci., 4, 222-226, https://doi.org/10.1038/ngeo1078. 
Vigaud, N., Y. Richard, M. Rouault, and N. Fauchereau, 2009: Moisture transport between the South Atlantic Ocean and southern Africa: Relationships with summer rainfall and associated dynamics. Climate Dyn., 32, 113-123, https://doi.org/ 10.1007/s00382-008-0377-7.

Washington, R., R. James, H. Pearce, W. M. Pokam, and W. Moufouma-Okia, 2013: Congo Basin rainfall climatology: Can we believe the climate models? Philos. Trans. Roy. Soc., 368, 20120296, https://doi.org/10.1098/rstb.2012.0296.

Webster, P. J., 1983: Large-scale structure of the tropical atmosphere. Large-Scale Dynamical Processes in the Atmosphere, B. J. Hoskins and R. P. Pearce, Eds., Academic Press, 235-275.
Xie, P., and P. A. Arkin, 1997: Global precipitation: A 17-year monthly analysis based on gauge observations, satellite estimates and numerical model outputs. Bull. Amer. Meteor. Soc., 78, 2539-2558, https://doi.org/10.1175/1520-0477(1997) 078<2539:GPAYMA $>2.0$.CO;2.

Yu, B., and F. W. Zwiers, 2010: Changes in equatorial atmospheric zonal circulations in recent decades. Geophys. Res. Lett., 37, L05701, https://doi.org/10.1029/2009GL042071.

— _ — - G. J. Boer, and M. F. Ting, 2012: Structure and variances of equatorial zonal circulation in a multimodel ensemble. Climate Dyn., 39, 2403-2419, https://doi.org/10.1007/ S00382-012-1372-6. 